\title{
Articles
}

Hans-W. Micklitz and Betül Kas

\section{Overview of cases before the CJEU on European Consumer Contract Law (2008-2013) - Part I}

\author{
The research leading to these results has received \\ funding from the European Research Council under \\ the European Union's Seventh Framework Programme \\ (FP/2007-2013)/ERC Grant Agreement n [269722]
}

\begin{abstract}
During the last five years the CJEU had to decide on more than 50 preliminary references in the area of consumer contract law. As a consequence there are far more than 100 decisions available which represent the increasingly concrete basis for a European contract law. Particularly striking is the rising number of questions referred to the CJEU by the new Member States. With regard to quantity two fields stand out: legal conflicts about financial services of all kinds and about passenger rights. Since the CJEU has developed independent dogmatics for some areas of contract law, it might be necessary to rethink legal categories on the national level.
\end{abstract}

Résumé: Durant les cinq dernières années, la CJUE a dû répondre à plus de 50 questions préjudicielles dans le domaine du droit des contrats de consommation. En conséquence, il y a bien plus de 100 décisions disponibles qui représentent une base concrète croissante pour un droit européen des contrats. L'accroissement du nombre de questions adressées à la CJUE par les nouveaux Etats membres est particulièrement frappant. Quantitativement, deux domaines se distinguent: les conflits juridiques relatifs aux services financiers de toutes sortes et ceux relatifs aux droits des passagers. Comme la CJUE a développé des interprétations propres dans quelques domaines du droit des contrats, il pourrait être nécessaire de repenser les catégories juridiques au niveau national.

Zusammenfassung: In den letzten fünf Jahren hatte der EuGH mehr als 50 Vorlageverfahren im Bereich des Verbrauchervertragsrechts $\mathrm{zu}$ entscheiden. Per dato liegen damit weit mehr als 100 Entscheidungen vor, die in immer dichterer Form die Grundlagen für ein europäisches Vertragsrecht konkretisieren. Auffällig ist 
die steigende Zahl von Vorlagen aus den neuen Mitgliedstaaten. In der Sache dominieren in quantitativer Hinsicht zwei Bereiche: rechtliche Auseinandersetzungen um Finanzdienstleistungen jedweder Art und das Passagier- bzw. Reiserecht. Für Teilbereiche des Vertragsrechts entwickelt der EuGH eine eigenständige Dogmatik, die ein Überdenken nationaler rechtlicher Kategorien notwendig macht.

Keywords: consumer law, unfair terms, doorstep selling, distance selling, sale of consumer goods

Prof. Hans-W. Micklitz: European University Institute Department of Law, Via Boccaccio 121, 50133 Florence, Italy, E-Mail: Hans.Micklitz@EUl.eu

Betül Kas: European University Institute Department of Law, Via Boccaccio 121, 50133 Florence, Italy, E-Mail: Betul.Kas@EUI.eu

\section{Part I}

I Contract Law

1 Unfair terms in consumer contracts

2 Doorstep selling

3 Distance selling

4 Sale of consumer goods

\section{Part II (Next issue)}

II Travel Law

1 Passenger rights in air traffic

2 Integration into the case-law

3 Travel marketing and travel insurance

III Financial services

1 Consumer credit

2 Insurance law and consumer protection

IV Anti-discrimination law and consumer protection

V Legal protection

1 Jurisdiction over consumer contracts

2 Alternative dispute settlement

VI Overview in tabular form 


\section{Part I}

\section{Contract Law}

1 Unfair terms in consumer contracts (Case C-243/08 Pannon GSM; case C-40/08 Asturcom Telecomunicaciones; case C-484/08 Caja de Ahorros y Monte de Piedad de Madrid; case C-137/08 VB Pénzügyi Lízing; case C-453/10 Pereničová and Perenič; case C-472/10 Invitel; case C-618/10 Banco Español de Crédito; case C-472/11 Banif Plus Bank; case C-415/11 Aziz; case C-92/11 RWE Vertrieb; case C-488/11 Asbeek Brusse and de Man Garabito; case C-397/11 Jörös; case C-413/12 Asociación de Consumidores Independientes de Castilla y León; case C-482/12 Macinský and Macinská; case C-470/12 Pohotovost)

a) Obligation of the national court to examine of its own motion the unfairness of a term conferring jurisdiction (Case C-243/08 Pannon GSM)

aa) Facts

The Hungarian Budaörsi Városi Bíróság referred to the European Court of Justice (CJEU) the question of whether the non-binding nature of an unfair term is the consequence of an ipso jure effect of Article 6(1) of Directive 93/13/EEC ${ }^{1}$ or whether the consumer has to contest the validity of such a term by lodging the relevant application. The referring court raised furthermore the question of whether the obligation of the national court to rule of its own motion on the unfairness of a contractual term exists irrespective of the type of action and which factors it must consider in assessing the possible unfairness of the contractual term.

The parties entered into a subscription contract for the provision of mobile telephone services. Under the terms and conditions, the two parties accepted that the court for the place where Pannon has its principal place of business has jurisdiction for any dispute arising from the subscription contract or in relation to it. Pursuant to that term, Pannon applied to the Budaörs District Court for an order

1 Council Directive 93/13/EEC of 5 April 1993 on unfair terms in consumer contracts, OJ 1993 L95/ 29; for a recent assessment of the case-law relating to the Directive, see also N. Gavrilovic, 'The Unfair Contract Terms Directive through the Practice of the Court of Justice of the European Union: Interpretation or Something More?' (2013) 2 European Review of Contract Law 193. 
for payment. The consumer then filed a statement of opposition to that order without questioning the court's territorial jurisdiction. Although the court had doubts about the validity of the jurisdiction clause, it was prevented from questioning its territorial jurisdiction because the consumer already made the first filing of her defence to the substance of the dispute.

\section{bb) Main reasoning}

The CJEU held that the non-binding nature of an unfair contract clause does not require the consumer to have successfully contested the validity of such a term beforehand. ${ }^{2}$ Relying on its earlier rulings in Cofidis ${ }^{3}$ and Mostaza Claro, ${ }^{4}$ the CJEU emphasized the obligation of the national court to determine the unfairness of a term of its own motion, once it has the necessary legal and factual elements necessary for that task. This obligation also exists as regards the assessment of its own territorial jurisdiction. Without this power, the consumer's own unawareness of his rights or fear of the costs of an action could lead him to not exercise his rights. ${ }^{5}$ This does not exclude the possibility that the term in question may be applicable, if the consumer, after having been informed of it by that court, decides not to assert its unfair or non-binding status. ${ }^{6}$ The CJEU also pointed to its finding in Océano Grupo $^{7}$ that a jurisdiction clause may be regarded as unfair. Nevertheless, the CJEU with reference Freiburger Kommunalbauten, ${ }^{8}$ left it to the national courts to assess the possible unfairness of a particular term in the light of the particular circumstances of the case. ${ }^{9}$

2 Case 243/08 Pannon GSM Zrt v Erzsébet Sustikné Györfi [2009] ECR I-4713 (CJEU), paragraph 24.

3 Case 473/00 Cofidis SA v Jean-Louis Fredout [2002] ECR I-10875 (CJEU); discussed by J.W. Rutgers, (2005) 1 European Review of Contract Law 87.

4 Case 168/05 Elisa María Mostaza Claro v Centro Móvil Milenium SL [2006] ECR I-10421 (CJEU); discussed by M.B.M. Loos, (2007) 4 European Review of Contract Law 439; see also N. Reich, 'More clarity after “Claro”?' (2007) 1 European Review of Contract Law 41.

5 Case 243/08, n 2 above, paragraphs 30-32.

6 Case 243/08, n 2 above, paragraph 33.

7 Joined cases 240/98 to 244/98 Océano Grupo Editorial SA et al v Roció Murciano Quintero et al [2000] ECR I-4941 (CJEU); discussed by Rutgers, $\mathrm{n} 3$ above, 87.

8 Case 237/02 Freiburger Kommunalbauten GmbH Baugesellschaft \& Co KG v Ludger Hofstetter and Ulrike Hofstetter [2004] ECR I-3403 (CJEU); discussed by M.W. Hesselink, (2006) 3 European Review of Contract Law 366.

9 Case 243/08, n 2 above, paragraphs 40-43. 


\section{cc) Integration in the case-law}

The ruling provides clarification from the CJEU that the national courts are under an obligation to carry out an ex officio examination. In Océano Grupo, the CJEU went only towards a power of ex officio examination. In Cofidis the CJEU had already adopted an obligation of ex officio examination, which was stated even more clearly in Mostaza Claro. ${ }^{10}$ A new element is that the consumer may decide to not assert the unfair status of a clause after prior notice of it by the national court. This regulation is consistent with the idea of consumer protection through information. In accordance with the principle of party autonomy, the CJEU takes into account that it may be in the interest of the consumer to enforce the clause in individual cases and to avoid the consumer from having a protection forced upon him. ${ }^{11}$

A point of discussion in the literature is the division of competence between the CJEU and national courts. In Océano Grupo it was assumed that the CJEU has taken a comprehensive control over the final determination of the unfairness of a jurisdiction clause. ${ }^{12}$ In Freiburger Kommunalbauten, however, the CJEU stressed that the final assessment of the unfairness of a particular contract clause is to be made by the national courts. The task of the CJEU is confined to the interpretation of general evaluation criteria. ${ }^{13}$ In Pannon GSM, the CJEU tries to bring its decisions in Océano Grupo and Freiburger Kommunalbauten into conformity. The jurisdiction clause may be regarded as unfair, but the final assessment is left to the Hungarian court. ${ }^{14}$ The CJEU clarifies that it had only established general criteria for the definition of unfairness in Océano Grupo. ${ }^{15}$

10 A. Ancery and M. Wissink, case note, (2010) 2 European Review of Private Law 307, 308, 313; J. Stuyck, case note, (2010) 3 Common Market Law Review 879, 892; C. Cheneviere, case note, (2010) 2 Revue européenne de droit de la consommation 351, 354; Rutgers, n 3 above, 89, 90; Loos, n 4 above, 443, 444; Heinig emphasizes that the obligation to examine ex officio the unfairness of a clause results in no undue interference with the regulatory autonomy of the Member States, see J. Heinig, 'Die AGB-Kontrolle von Gerichtsstandsklauseln - zum Urteil Pannon des EuGH' (2009) 24 Europäische Zeitschrift für Wirtschaftsrecht 885.

11 Heinig, n 10 above, 886; Ancery and Wissink, n 10 above, 313. Osztovits and Nemessányi are therefore of the view that the principle pacta sunt servanda prevailed over the non-binding nature of unfair terms, see A. Osztovits and Z. Nemessányi, 'Missbräuchliche Zuständigkeitsklauseln in der Ungarischen Rechtsprechung im Licht der Urteile des EuGH' (2010) 2 Zeitschrift für Europarecht, Internationales Privatrecht und Rechtsvergleichung 22, 25.

12 Heinig, n 10 above, 886. Although ambiguous, see Stuyck, n 10 above, 892, 894.

13 Hesselink, n 8 above, 366; Loos, $\mathrm{n} 4$ above, 444.

14 Critical of such a delegation to the national court at the expense of a Community-wide harmonization, see Heinig, n 10 above, 886; for a more positive view, see Ancery and Wissink, n 10 above, 315.

15 According to Pfeiffer, the CJEU reached this result only in a 'severe bending' of Océano Grupo and yet 'between the lines' everything would speak nevertheless for unfairness of such a clause, 


\section{b) Annulment of a final arbitration award in case of an unfair arbitration clause (Case C-40/08 Asturcom Telecomunicaciones)}

\section{aa) Facts}

The Spanish Juzgado de Primera Instancia No 4 de Bilbao asked whether it is necessary for the national court hearing an action for enforcement of a final arbitration award, made in the absence of the consumer, to determine of its own motion whether the arbitration agreement is void and, accordingly, to annul the award if it finds that the arbitration agreement contains an unfair arbitration clause that is to the detriment of the consumer.

The consumer did not pay some of her telephone bills and terminated her contract before the agreed minimum subscription period had expired. The arbitration tribunal ruled in favor of Asturcom. The consumer had neither participated in the arbitration proceedings, nor filed a claim for annulment of the award. The court hearing the action for enforcement of the arbitration award assumed the unfairness of the arbitration clause. However, the Spanish law on civil procedure does not contain any provision dealing with the assessment to be carried by the court as to whether arbitration clauses are unfair when adjudicating on an action for enforcement of an arbitration award that has become final.

\section{bb) Main reasoning}

The CJEU emphasized at the outset the importance, both for the Community legal order and for the national legal systems, of the principle of res judicata.The principles of effectiveness and equivalence limit the application of the national procedural law implementing the principle of res judicata. ${ }^{16}$ The current twomonth time-limit in Spain for challenging an arbitration award is consistent with

see T. Pfeiffer, 'Prüfung missbräuchlicher Klauseln von Amts wegen (Gerichtsstand) - Günstigkeitsprinzip nach Wahl des Verbrauchers' (2009) 32 Neue Juristische Wochenschrift 2367, 2369; also Heinig, n 10 above, 887; Stuyck, n 10 above, 894.

16 Case 40/08 Asturcom Telecomunicaciones SL v Cristina Rodríguez Nogueira [2009] ECR I-9579 (CJEU), paragraphs 35-38; discussed by C. Mak, (2010) 4 European Review of Contract Law 437. The CJEU refers to the following case law, case 126/97 Eco Swiss China Time Ltd v Benetton International NV [1999] ECR I-3055 (CJEU); case 234/04 Rosmarie Kapferer v Schlank \& Schick GmbH [2006] ECR I-2585 (CJEU); case 2/08 Amministrazione dell'Economia e delle Finanze and Agenzia delle Entrate v Fallimento Olimpiclub Srl [2009] ECR I-7501 (CJEU); on breaching the principle of res judicata in order to ensure the effectiveness of Union law, see: S. Schmahl and M. Köber, 'Durchbrechung der Rechtskraft nationaler Gerichtsentscheidungen zu Gunsten der Effektivität des Unionsrechts?' (2010) 24 Europäische Zeitschrift für Wirtschaftsrecht 927. 
the principle of effectiveness. ${ }^{17}$ The need to comply with the principle of effectiveness cannot be stretched so far as to mean that a national court is required to make up fully for the total inertia on the part of the consumer concerned who, like the defendant in the national proceedings at hand, neither participated in the arbitration proceedings nor brought an action for annulment of the arbitration award, which therefore became final. Consequently, the Spanish procedural rules would not make it impossible or excessively difficult for the consumer to exercise his rights in accordance with Directive 93/13/EEC. ${ }^{18}$ The CJEU left it to the national court to examine the compliance with the principle of equivalence. The obligation to examine the possible unfairness of an arbitration clause exists if the national procedural law allows the court, of its own motion, to review an arbitration clause because of a possible breach of national public policy rules. ${ }^{19}$ If so, it is for the referring court to give due effect, in accordance with national law, to any finding in relation to the arbitration award that an arbitration clause is unfair, so long as the clause is not capable of binding the consumer. ${ }^{20}$ In contrast to the CJEU, Advocate-General Trstenjak, the Commission, as well as both the Hungarian and Spanish governments, took the view that the national court must have the power in enforcement proceedings to determine of its own motion whether an arbitration clause is unfair and to annul that clause. According to Advocate-General Trstenjak, in view of the need for effective consumer protection, it may be necessary, in exceptional cases, to disregard the principle of res judicata. ${ }^{21}$

\section{cc) Integration in the case-law}

In Mostaza Claro, ${ }^{22}$ the CJEU held that a national court seised of an action for annulment of an arbitration award must determine whether the arbitration agree-

17 Case 40/08, n 16 above, paragraphs 39-46. The time-limit in question is in accordance with the principle of effectiveness for two main reasons: Firstly, the time period grants the consumer sufficient time to assess whether there are grounds for challenging the award and, if necessary, prepare the action for annulment of the award. Secondly, the time-limit only begins to run from the date of notification of the arbitration award.

18 Case 40/08, n 16 above, paragraphs 47, 48.

19 Case 40/08, n 16 above, paragraphs 49-56.

20 Case 40/08, n 16 above, paragraph 58.

21 AG Trstenjak, opinion of 14.5.2009 - case 40/08, n 16 above, paragraphs 58, 75, 76. As the Advocate-General highlighted at para 64, otherwise national law would expect the consumer to take part in invalid proceedings in order to be able to have the contract annulled. Such an outcome would be unacceptable and shows that the court responsible for enforcement must have an appropriate power of review.

22 Case 168/05, n 4 above, paragraphs 38, 39. 
ment is void and annul that award where that agreement contains an unfair term, even though the consumer has not pleaded that invalidity in the course of the arbitration proceedings, but only in that of the action for annulment. Unlike Mostaza Claro, the consumer in the case at hand 'did not in any way become involved' in the various proceedings and, in particular, did not bring an action for annulment of the arbitration award so that that award then had the force of res judicata. ${ }^{23}$ The recognition of the principle of res judicata by the CJEU restricts the consumer protection declared in Mostaza Claro from unfair arbitration clauses. ${ }^{24}$ The CJEU, however, goes a step further than the principle of equivalence usually provides since the CJEU defines the relevant benchmark itself: Article 6(1) of Directive 93/13/EEC must be considered as a provision which is equivalent to national rules of public policy. ${ }^{25}$ The CJEU, as it had already indicated in Mostaza Claro, confirmed that Article 6(1) is anchored as part of the public policy. ${ }^{26}$ This element led to wide-ranging discussions in the literature on the relationship between public policy and mandatory rules of contract law. ${ }^{27}$

The judgment does not lead to a harmonization of the national courts' obligation in enforcement procedures to carry out an examination of the unfairness of arbitration clauses. In Spain there was no legal rule or uniform practice giving the court a power to reject an application for enforcement by reference to public policy. In the subsequent judgment, the Bilbao court of first instance enforced the arbitration award without examining the unfairness of the arbitration clause. ${ }^{28}$ Additionally, it should be noted that in Asturcom Telecomunicaciones the CJEU

23 Case 40/08, n 16 above, paragraph 33.

24 Stuyck, n 10 above, 894; K. Hilbig, 'Absoluter Verbraucherschutz bei unzulässigen AGBSchiedsvereinbarungen?' (2010) 2 Zeitschrift für Schiedsverfahren 74, 81; Mak criticizes that the CJEU declined to make a comparison with Océano Grupo and thus missed the opportunity of imposing the obligation to assess the unfairness of the arbitration clause on the arbitration tribunal, see Mak, n 16 above, 442-444.

25 M. Ebers, case note, (2010) 4 European Review of Private Law 823, 839; H. Schebesta, 'Does the National Court Know European Law? A Note on Ex Officio Application after Asturcom'(2010) 4 European Review of Private Law 847, 872.

26 Case 168/05, n 4 above, paragraphs 35-38; Loos, n 4 above, 443, 444.

27 As the Advocate-General Tizzano previously pointed out in his opinion delivered on 27.4. 2006 in Mostaza Claro at para 56, the danger is that 'it might give excessively wide scope to a concept, namely that of public policy, which traditionally refers only to rules that are regarded as being of primary and absolute importance in a legal order'; Ebers, n 25 above, 843-846; Stuyck, n 10 above, 891-897; Schebesta, n 25 above, 864-870; Hilbig, n 24 above, 79-81; Mak, n 16 above, 445-447.

28 Mak, n 16 above, 446-447. 
again declined the opportunity to set uniform standards for testing the fairness of an arbitration clause. ${ }^{29}$

\section{c) Minimum protection standard of the substantive assessment of contract terms under Article 4(2) of Directive 93/13/EEC (Case C-484/08 Caja de Ahorros y Monte de Piedad de Madrid)}

\section{aa) Facts}

In the reference for a preliminary ruling from the Spanish Tribunal Supremo, the question was whether, given the minimum harmonisation standard set out by Directive 93/13/EEC, a Member State may provide in its legislation, for the benefit of consumers, that the assessment as to whether contractual terms are unfair is to be carried out also in respect of terms which, pursuant to Article 4(2), fall outside the scope of such an assessment. According to Article 4(2), the assessment of the unfair nature of the terms shall relate neither to the definition of the main subject-matter of the contract nor to the adequacy of the price and remuneration, in so far as these terms are in plain, intelligible language. As Spain had not transposed Article 4(2) into its legal system, it did not provide for such a limitation.

In the dispute at hand, the Asociación de Usuarios de Servicios Bancarios (Ausbanc - Association of users of banking services) initiated an action for an injunction against Caja de Ahorros y Monte de Piedad de Madrid (Caja de Madrid). The action was directed against the use of a 'rounding-up term' in variable-rate consumer loan agreements used for the purchase of residential property. ${ }^{30}$

\section{bb) Main reasoning}

The Commission, the Spanish Government and Ausbanc contested the admissibility of the reference for a preliminary ruling. It was submitted that the roundingup term does not concern the main subject-matter of the contract, but constitutes a subsidiary element to it, with the result that Article 4(2) of the Directive is not applicable to the dispute. However, the CJEU clarified that accord-ing to its settled

29 Already thus in Mostaza Claro, see Reich, n 4 above, 43.

30 Pursuant to this clause, the nominal interest rate, variable from time to time in accordance with the agreed reference index, is rounded up to the next quarter of a percentage point with effect from the first revision. 
case-law, it is solely for the national court to assess the need for a preliminary ruling and the relevance of the question to be submitted. ${ }^{31}$

The CJEU ruled that the Spanish legislation does not contravene EU law. As is apparent from the $12^{\text {th }}$ recital and Article 8 of Directive 93/13/EEC, the Directive carried out only a partial and minimum harmonisation of national legislation concerning unfair terms, while recognising that Member States have the option of affording consumers a higher level of protection than that for which the Directive provides. The Directive formally lays down the option for Member States to 'adopt or retain [more] stringent provisions compatible with the Treaty in the area covered by [the] Directive, to ensure a [greater] degree of protection for the consumer'. ${ }^{32}$ Contrary to what Caja de Madrid argued, Article 4(2) of the Directive cannot be regarded as laying down the scope ratione materiae of the Directive. Article 4(2) is concerned solely with establishing the detailed rules permitting an assessment as to whether the contract terms subject to the provisions of the Directive are unfair. Thus, Article 8 applies to Article 4(2). ${ }^{33}$

\section{cc) Integration in the case-law}

Advocate-General Trstenjak referred to 'the tension between the parties' freedom to arrange their own affairs and the need for statutory intervention in favour of consumer protection'. ${ }^{34}$ Article 4(2) was first introduced through an amendment of the Council. The literature indicates that the inclusion of Article 4(2) constituted a value-based decision of the Community legislature in the interest of the parties' freedom to arrange their own affairs and in the interest of a functioning market based on competition in respect of price and efficiency..$^{35}$ The relationship between performance and consideration is governed by the law of supply and demand. Paragraph 8 of the German Law on general business conditions (AGBG) (now $\S 307(3)$ of the German Civil Code (BGB)) is seen as a template for this provision. ${ }^{36}$

The CJEU decision is consistent with the minimum harmonization nature of the Directive. The lack of implementation of Article 4(2) into Spanish law is not

31 Case 484/08 Caja de Ahorros y Monte de Piedad de Madrid v Asociación de Usuarios de Servicios Bancarios (Ausbanc) [2010] ECR I-4785 (CJEU), paragraphs 18-23; discussed by J. Stuyck, (2010) 4 European Review of Contract Law 449.

32 Case 484/08, n 31 above, paragraphs 28, 29.

33 Case 484/08, n 31 above, paragraphs 32-35.

34 AG Trstenjak, opinion of 29.10.2009 - case 484/08, n 31 above, paragraph 64.

35 AG Trstenjak, n 34 above, paragraphs 61 et seq.

36 Stuyck, n 31 above, 451-454. 
contrary to the consumer protection objective of the Directive. The CJEU differentiates the present situation from that in Commission v Netherlands. ${ }^{37}$ In that case, the CJEU held that the Kingdom of the Netherlands had failed to fulfil its obligations under the Directive, not by failing to transpose Article 4(2) thereof, but by failing to transpose it in full, with the result that any possibility of judicial review of terms describing the essential obligations, even where the drafting of those terms was obscure and ambiguous, was excluded. ${ }^{38}$ The two judgments illustrate the nature of the directive, which, according to Article 288 TFEU, is binding regarding the result to be achieved, while granting the Member State the choice of form and methods. ${ }^{39}$

\section{d) Division of competences between the CJEU and the national courts; Ex officio investigation of the legal and factual elements necessary for the examination of a term; Upgrading of the indicative list (Case C-137/08 VB Pénzügyi Lízing)}

\section{aa) Facts}

The Hungarian Budapesti II és III Kerületi Bíroság wanted to know whether the jurisdiction of the CJEU extends to the interpretation of the concept of 'unfair term' referred to in Article 3(1) of Directive 93/13/EEC, the terms listed in the Annex to that Directive as well as the criteria to examine a particular term. It also asked whether the national court is obliged to undertake, of its own motion, an investigation with a view to establishing the factual and legal elements necessary to assess whether a term is unfair. Hungarian law permits such an examination only at the request of either party.

In the dispute at hand, the company brought an action before the referring court for the repayment of a debt when the consumer ceased to fulfil his contractual obligations under a loan contract to finance the purchase of a car. The company did not bring its application for a payment order before the court where the consumer lived, nor where it was headquartered itself, but relied on a term included in the loan contract which conferred jurisdiction in any dispute between the parties on the court making the reference.

37 Case 144/99 Commission v Kingdom of the Netherlands [2001] ECR I-3541 (CJEU).

38 Case 484/08, n 31 above, paragraphs 36-39.

39 R. Tamas, case note, (2011) 2 Revue européenne de droit de la consommation 403, 410-412; For an analysis of the judgment in relation to the UK Bank Charges case: S. Whittaker, 'Unfair Contract Terms, Unfair Prices and Bank Charges' (2011) 1 Modern Law Review 106. 


\section{bb) Main reasoning}

The CJEU referred to its reasoning in Pannon $G S M .^{40}$ According to Article 267 TFEU, the CJEU may be called upon by a national court to interpret concepts appearing in an instrument of secondary law, such as the concept of 'unfair term' used in Article 3(1) of the Directive and its Annex, as well as the factors which the national court must consider in assessing the possible unfairness of a contractual term. Nevertheless, it is for the national court to determine whether a particular term satisfies the criteria to be categorised as 'unfair' in light of the circumstances of the concrete case. ${ }^{41}$ The CJEU explained the obligation of national courts on the basis of a two-step test. In the first step, the national court must examine the applicability of the Directive according to Article 1 in conjunction with Article 3 of the Directive. Specifically, it must determine whether or not the exclusive territorial jurisdiction clause was individually negotiated between the seller or supplier and the consumer. If the Directive applies, in the next step it must check the unfair nature of the jurisdiction clause. ${ }^{42}$ The CJEU recalled Océano Grupo ${ }^{43}$ in which a territorial jurisdiction clause in favor of the principal place of business of the seller or supplier was qualified as unfair. Even though the clause in question does not confer jurisdiction to the courts where the supplier or seller has his principal place of business, it obliges the consumer to submit to the exclusive jurisdiction of a court which may be a long way from his domicile. Consequently, such a term falls within the group of clauses mentioned in point 1(q) of the Annex. ${ }^{44}$

\section{cc) Integration in the case-law}

The CJEU consolidated the division of competences between the CJEU and national courts as established in Pannon GSM. The CJEU is responsible for the interpretation of the criteria of unfairness stated in the Directive including the Annex, while the actual application is left to the national courts..$^{45}$ VB Pénzügyi Lizing marked a turning point in the case law of the CJEU, the meaning of which has only been revealed in subsequent decisions. Although the CJEU leaves a margin of interpretation to the national courts, it provides increasingly concrete

40 Case 243/08, n 2 above, paragraphs 37-39, 44.

41 Case 137/08 VB Pénzügyi Lízing Zrt v Ferenc Schneider [2010] ECR I-10847 (CJEU), paragraphs 39-43; discussed by W.H. Roth, (2011) 3 European Review of Contract Law 425.

42 Case 137/08, n 41 above, paragraphs 49-52.

43 Joined cases 240/98 to 244/98, n 7 above.

44 Case 137/08, n 41 above, paragraphs 53-55.

45 T. Pfeiffer, case note, (2010) 12 LMK Anmerkung, 311868. 
guidance on how national courts have to understand the rules of the Directive. Advocate-General Trstenjak emphasized that the task of the CJEU is 'gradually to give specific expression to the abstract criteria for reviewing whether a term may be classified as unfair and, with increasing experience, to establish a profile for reviewing the unfairness of terms at the level of community law. ${ }^{46}$ It appears that the Annex does not merely have an indicative function, but serves as a starting point for assessing and justifying the unfair character of a clause listed therein. ${ }^{47}$ Finally, it should be noted that Advocate-General Trstenjak declined the recognition of a general obligation of the national court to undertake an investigation of its own motion for the purpose of obtaining the legal and factual elements necessary to assess the unfairness of a contractual term. ${ }^{48}$

\section{e) Effect of unfair commercial practices and unfair terms on the validity of the contract as a whole; Coherent interpretation of consumer protection law (Case C-453/10 Pereničová and Perenič)}

\section{aa) Facts}

The Slovak Okresný súd Prešov asked if Article 6(1) of Directive 93/13/EEC makes it possible, where unfair contractual clauses are found in a consumer contract, to conclude that the contract as a whole is not binding on the consumer, if that is more advantageous to the consumer. The court also wanted to know whether the specification of a level lower than the real annual percentage rate in a consumer credit contract is an unfair commercial practice under Directive 2005/29/EC, ${ }^{49}$ and if so, what the consequences of this were for assessing the unfairness and the validity of the contract in accordance with the Directive 93/13/EEC.

The reference has been made in the course of proceedings prompted by an action brought by Mr and Mrs Perenič for the annulment of the consumer credit agreement concluded between them and a non-bank institution. They claim that the agreement contains many terms worded to their disadvantage, including an

46 AG Trstenjak, opinion of 6.7.2010 - case 137/08, n 41 above, paragraph 99.

47 N. Reich and H.-W. Micklitz, 'AGB-Recht und UWG - (endlich) ein Ende des Kästchendenkens nach EuGH Pereničová und Invitel?’ (2012) 7 Europäisches Wirtschafts- und Steuerrecht 257, 259.

48 AG Trstenjak, n 46 above, paragraph 110. Concurring with the Advocate-General, Pfeiffer, n 45 above.

49 Directive 2005/29/EC of the European Parliament and of the Council of 11 May 2005 concerning unfair business-to-consumer commercial practices in the internal market and amending Council Directive 84/450/EEC, Directives 97/7/EC, 98/27/EC and 2002/65/EC of the European Parliament and of the Council and Regulation (EC) No 2006/2004 of the European Parliament and of the Council, OJ 2005 L149/22. 
incorrectly calculated annual percentage rate (APR). They therefore conclude that the agreement must be declared invalid as a whole, the interests of consumer protection being inadequately safeguarded by only partial invalidity.

\section{bb) Main reasoning}

The CJEU emphasized the obligation of national courts to draw all the consequences that follow under national law to ensure that the consumer is not bound by those terms. In assessing then whether the contract can exist without the unfair terms, the national court must not consider the situation of one of the parties to the contract, in this case the consumer, as the decisive criterion determining the fate of the contract. This objective approach flows from the wording of Article 6(1) of Directive 93/13/EEC and the requirements of legal certainty of economic activities. The national court must take account of the objective pursued by the legislature of restoring the balance between the parties while in principle preserving the validity of the contract as a whole, not in abolishing all contracts containing unfair terms. ${ }^{50}$ The minimum harmonisation nature the Directive, however, does allow for national legislation under which a contract concluded between a trader and a consumer which contains one or more unfair terms may be declared void as a whole where that will ensure better protection of the consumer. ${ }^{51}$

Regarding the second question, the CJEU bases its view on a broad definition of 'commercial practice' in Article 2(d) of Directive 2005/29/EC. The indication of a miscalculated APR constitutes a 'misleading' commercial practice within the meaning of Article 6(1)(e) if it causes or is likely to cause the average consumer to take a transactional decision that he would not have taken otherwise. ${ }^{52}$ Due to the broadly-defined criteria for assessing the unfairness of a contractual clause in Article 4(1) of Directive 93/13/EEC, a finding that a commercial practice is unfair is one element among others on which the national court may base its assessment of the unfairness of contractual terms. That element, however, is not such as to establish, automatically and on its own, that the contested terms are unfair. ${ }^{53}$ The failure to properly indicate the APR has no direct impact on the validity of a consumer credit agreement under Article 6(1) of Directive 93/13/EEC. Directive

50 Case 453/10 Jana Pereničová and Vladislav Perenič v SOS financ spol s r o 15.3.2012 (CJEU), paragraphs 29-33.

51 Case 453/10, n 50 above, paragraphs 34, 35; with reference to Article 8 of the Directive, and case 484/08, n 31 above, paragraphs 28, 29.

52 Case 453/10, n 50 above, paragraphs 38-41.

53 Case 453/10, n 50 above, paragraphs 42-44. 
2005/29 applies 'without prejudice to contract law and in particular to the rules on the validity, formation or effect of a contract'. ${ }^{54}$ The CJEU's judgment follows Advocate-General Trstenjak's opinion in full. ${ }^{55}$

\section{cc) Integration in the case-law}

Like Advocate-General Trestenjak, the CJEU also bases its reasoning on the principle of parity in the area of contractual autonomy, which excludes one-sided subjective legal consequences for the benefit of the consumer. ${ }^{56}$ The criteria according to which the contract cannot objectively exist any longer are not clarified by the CJEU. The ruling for the first time addressed the entanglement of consumer contract law and unfair commercial practices law, both from a procedural and a substantive perspective. ${ }^{57}$ Advocate-General Trstenjak stressed that the EU acts in the area of consumer protection law must be seen as 'part of a single, overall set of rules which complement each other', requiring a coherent interpretation of the relevant rules of law. ${ }^{58}$ The CJEU followed the AdvocateGeneral, and so shattered the prior established separation of the two areas of law in favor of an effective regime of consumer protection. Article 4(1) of Directive 93/ 13/EEC serves as a 'gateway' for assessments under the legislation on fair trading practices. ${ }^{59}$ Nevertheless, the legal consequences of a misleading indication of the APR on the validity of the concrete contract remain unclear. ${ }^{60}$ In addition, the CJEU does not provide clarity on whether the use of an unfair clause constitutes an unfair commercial practice. ${ }^{61}$ To clarify the relationship between the two

54 Case 453/10, n 50 above, paragraphs 45, 46.

55 AG Trstenjak, opinion of 29.11.2011 - case 453/10, n 50 above.

56 Critical on this aspect of the judgment, see H. Jacquemin, case note, (2012) 3 Revue européenne de droit de la consommation 575, 580.

57 H.-W. Micklitz and N. Reich, “'Und es bewegt sich doch'? - Neues zum Unionsrecht der missbräuchlichen Klauseln in Verbraucherverträgen” (2012) 4 Europäische Zeitschrift für Wirtschaftsrecht 126.

58 AG Trstenjak, n 55 above, paragraphs 88, 89.

59 Reich and Micklitz, n 47 above, 260; AG Trstenjak, n 55 above, paragraph 124.

60 Reich and Micklitz question whether a contractual clause which relates to an unfair or misleading advertisement can be valid in practice, see Reich and Micklitz, n 47 above, 260; Hennigs considers that the mere finding of an unfair commercial practice cannot establish the invalidity of a clause, see S. Hennigs, case note, (2012) 6 Gewerblicher Rechtsschutz und Urheberrecht $639,642$.

61 B. Keirsbilck, 'The interaction between consumer protection rules on unfair contract terms and unfair commercial practices: Perenicová and Perenic' (2013) 1 Common Market Law Review 247, 260; Hennigs, $n 60$ above, 642. 
Directives and to give a concrete structure to the meaning of a 'coherent' interpretation, further preliminary references will be necessary.

\section{f) Unfairness of an unilateral price amendment clause; Legal effects of an injunction on individual contracts (Case C-472/10 Invitel)}

\section{aa) Facts}

The Hungarian Pest Megyei Biróság asked under what conditions the clause at issue, which allowed for a unilateral increase in price by the seller, may be qualified as unfair in accordance with Directive 93/13/EEC. It also asked whether the declaration of the invalidity of an unfair term, as a result of an action for injunction in the public interest, may produce effects with regard to all consumers (including those who were not party to the proceedings) and whether the national courts must also, in future and of its own motion, draw all the consequences which are provided in national law in case of the unfairness of a term.

Due to numerous consumer complaints, the Hungarian Consumer Protection Office (Nemzeti Fogyasztóvédelmi Hatóság NFH) initiated a public interest action against the fixed-line telephone network operator Invitel. Invitel had introduced into its general business conditions a price amendment clause providing for 'money order fees' to be applied in the event of payment by money order without any provision specifying the method of calculation of those fees. The Consumer Protection Office requested the Hungarian court for a finding that the term in question is void and for refund of these costs and expenses.

\section{bb) Main reasoning}

The CJEU referred to the division of competences between the CJEU and the national courts as confirmed in VB Pénzügyi Lízing. ${ }^{62}$ The competence of the CJEU is limited to giving the national court indications on the assessment of the unfairness of the price amendment clause at hand. ${ }^{63}$ The exclusion in Article 4(2) cannot apply to a term relating to a 'mechanism for amending the prices of the services provided to the consumer'. ${ }^{64}$ To determine the assessment criteria, the CJEU referred to points $1(\mathrm{j})$ and (l) and points $2(\mathrm{~b})$ and (d) of the Annex. The Annex constitutes the 'essential element' on which the competent court may base its

62 Case 137/08, n 41 above, paragraph 44.

63 Case 472/10 Nemzeti Fogyasztóvédelmi Hatóság v Invitel Távközlési Zrt 26.4.2012 (CJEU), paragraph 22.

64 Case 472/10, n 63 above, paragraph 23. 
assessment as to the unfair nature of that term. However, the Annex does not suffice in itself to establish automatically the unfair nature of a contested term under Article 3(1) of the Directive. ${ }^{65}$ The national court must consider whether 'the reasons for, or the method of, the amendment of fees connected with the service to be provided are set out in plain, intelligible language and, as the case may be, whether consumers have a right to terminate the contract.' ${ }^{66}$

The effective implementation of Article 6(1) in connection with Article 7(1) and (2) of the Directive requires that terms of consumer contracts which are declared to be unfair in an action for an injunction brought against the seller or supplier concerned are not binding on either the consumers who are parties to the actions or on those who have concluded a contract with that seller or supplier to which the same terms apply. ${ }^{67}$ To ensure the deterrent nature and dissuasive purpose of an action for an injunction, such actions may be brought even though the terms which it is sought to have prohibited have not been used in specific contracts. ${ }^{68}$ The national courts are required, of their own motion, and also as regards the future, to draw all the consequences provided for by national law in order to ensure that consumers who have concluded a contract to which those terms apply will not be bound by that term. ${ }^{69}$ Other types of adequate and effective penalties in national legislation are not excluded. ${ }^{70}$ Advocate-General Trstenjak pointed out that the legal recognition of a right to refund of costs and expenses charged by the service provider on the basis of unfair terms meets the requirements for the authorisation granted under Article 8 of the Directive to be exercised in accordance with EU law. ${ }^{71}$

\section{cc) Integration in the case-law}

The preliminary reference by the Hungarian court offered the CJEU for the first time the possibility to take a position on the legal protection system of Directive 93/13/EEC and to clarify the relationship between individual and collective legal actions. ${ }^{72}$ The erga omnes effect of a finding of unfairness on individual contracts

65 Case 472/10, n 63 above, paragraph 26.

66 Case 472/10, n 63 above, paragraph 30.

67 Case 472/10, n 63 above, paragraph 38.

68 Case 472/10, n 63 above, paragraph 37.

69 Case 472/10, n 63 above, paragraphs 41-43.

70 Case 472/10, n 63 above, paragraph 40.

71 AG Trstenjak, opinion of 6.12.2011 - case 472/10, n 63 above, paragraphs 74-76.

72 R. Mathiak, case note, (2012) 20 Europäische Zeitschrift für Wirtschaftsrecht 786, 789; see also

B. Keirsbilck, 'The erga omnes effect of the finding of an unfair contract term: Nemzeti' (2013) 5 Common Market Law Review 1467. 
corresponds to the effet utile of the Directive. It remains unclear whether the erga omnes effect applies to every other seller or supplier using a similar term but not involved in the proceedings that led to the finding that the term in question was not binding. The Advocate-General replied in the negative in order to protect the right to be heard of persons who are not party to the proceedings. ${ }^{73}$ The CJEU takes no position on this issue, but does refer to the opinion of the AdvocateGeneral. ${ }^{74}$ However, the open wording of the CJEU in paragraph 40 might lead to the conclusion that it is possible to extend the non-binding nature of the unfair term to every other seller or supplier using a similar term. ${ }^{75}$

\section{g) Power of the national court in an order for payment procedure, to determine, of its own motion and in limine litis, that a term is unfair and should be modified (Case C-618/10 Banco Español de Crédito)}

\section{aa) Facts}

The Spanish Audiencia Provincial de Barcelona asked the CJEU to clarify whether a national court before which an application for an order for payment has been brought must assess of its own motion, in limine litis or at any other stage during the proceedings, whether a term relating to interest on late payments contained in a contract concluded between a seller or supplier and a consumer is unfair, in the case where that consumer has not lodged an objection. The second question was whether Article 6(1) of the Directive precludes a national rule that allows the court to modify the contract by revising the content of that term.

In the dispute at hand, the consumer entered into a loan agreement for the purchase of a vehicle. Due to a delay in the consumer's repayments, Banesto submitted an application in court for an order for payment for the outstanding monthly installments due under the contract together with interest and costs. The Spanish court ruled that the term concerning interest on late payments was void and reduced the interest from $29 \%$ to $19 \%$. The preliminary reference was made in the context of the appeal by Banesto against that order claiming that the court may not assess the agreed rate of interest on late payments of its own motion in limine litis, but only after an objection to that effect has been lodged by the defendant.

73 AG Trstenjak, $\mathrm{n} 71$ above, paragraph 60.

74 Case 472/10, n 63 above, paragraph 39.

75 Reich and Micklitz, n 47 above, 261; on this point, see also M. Bottino, case note, (2012) 3 Revue européenne de droit de la consommation 587, 590. 


\section{bb) Main reasoning}

The case at hand should be distinguished from the cases Pannon $G S M^{76}$ and VB Pénzügyi Lizing ${ }^{77}$ inasmuch as it concerns the tasks of the national court in the context of an order for payment procedure before the consumer has lodged an objection. ${ }^{78}$ Given that national mechanisms for recovery of uncontested claims are not harmonised, the CJEU refers to the principles of equivalence and effectiveness. ${ }^{79}$ The CJEU found no evidence of a breach of the principle of equivalence. ${ }^{80}$ However, the effectiveness of the protection intended by the Directive is liable to be undermined where the court may not assess of its own motion, in limine litis or at any other stage, whether terms contained in a contract are unfair where that consumer has not lodged an objection even though it already has all the legal and factual elements necessary for that task. To test the principle of effectiveness, the Court took into account the overall design of the Spanish procedure, such as the opposition period of 20 days, the fact that the assistance of a lawyer is required in cases exceeding a value of EUR 900, and the incomplete nature of the information on the application available to consumers. ${ }^{81}$ The CJEU did not follow the opinion of Advocate-General Trstenjak. The Advocate-General concurred with the unanimously held view of all the parties that it was sufficient for the consumer in respect of whom an application for an order for payment has been made to be given the opportunity to make a legal challenge by bringing an appeal. ${ }^{82}$

The CJEU held that the power of the national court to modify the content of an unfair term is not compatible with Article 6(1) of the Directive. ${ }^{83}$ As pointed out by Advocate-General Trstenjak, the modification of the unfair term in accordance with the law could in fact give the seller or supplier an incentive simply to 'try his luck' and to include as many unfair terms as possible in the agreement in the hope that most of them will be overlooked by the national court. ${ }^{84}$

76 Case 243/08, n 2 above.

77 Case 137/08, n 41 above.

78 Case 618/10 Banco Español de Crédito SA v Joaquín Calderón Camino 14.6.2012 (CJEU), paragraph 45; discussed by P. Rott, (2012) 4 European Review of Contract Law 470.

79 Case 618/10, n 78 above, paragraph 46.

80 Case 618/10, n 78 above, paragraphs 47, 48.

81 Case 618/10, n 78 above, paragraphs 49-57.

82 AG Trstenjak, opinion of 14.2.2012 - case 618/10, n 78 above, paragraph 74.

83 Case 618/10, n 78 above, paragraphs 65-73.

84 AG Trstenjak, n 82 above, paragraphs $86-88$. 


\section{cc) Integration in the case-law}

According to Advocate-General Trestenjak, 'the imposition of a duty to undertake a thorough investigation in the context of the order for payment procedure and to give a ruling in limine litis [...] would result in a fundamental modification of the operation of that procedure, which would eliminate an important efficiency benefit of the order for payment procedure, namely the quick enforcement of uncontested pecuniary claims. ${ }^{, 85}$ The CJEU emphasized, however, that the control must be present so as to prevent sellers or suppliers from initiating an order for payment procedure instead of an ordinary civil procedure in order to deprive consumers of the benefit of the protection intended by the Directive. ${ }^{86}$ Since the risk of circumvention is implicit in any terms and conditions, it could be assumed that this part of the judgment is not limited to terms concerning interest on late payments. In accordance with the broader regulatory function of the Directive 93/ 13/EEC, namely to prevent the continued application of unfair terms in consumer contracts, the CJEU clarified that the national court has to disapply the unfair contract term in its entirety and is not allowed to reduce the content to what is just fair. ${ }^{87}$ This result could have broad consequences, particularly for the practice of German courts. $^{88}$

85 AG Trstenjak, n 82 above, paragraph 56; for an integration of this ruling in the light of Pannon and VB Penzugyi Lizing and the ex officio investigation of the legal and factual elements necessary for the examination of a term, see V. Trstenjak, 'Procedural Aspects of European Consumer Protection Law and the Case Law of the CJEU' (2013) 2 European Review of Private 451.

86 Case 618/10, n 78 above, paragraph 55; concurring Rott, $n 78$ above, 472-475.

87 Rott, $\mathrm{n} 78$ above, 475-477.

88 The CJEU explicitly rejected the validity-preserving reduction (geltungserhaltende Reduktion) of unfair terms, which corresponds to the German approach. However, it is still unclear whether the gap left by an invalid clause may be closed by a supplementary interpretation of the contract (ergänzende Vertragsauslegung). In the Tagespreisklausel-decision (BGHZ 90, 69, 75, Neue Juristische Wochenschrift 1984, 1177, 1778) from 1984, the German Federal Court of Justice annulled, with the help of this legal construction, the potential effects of an invalid contract clause. Micklitz and Reich see this as a possible violation of Article 6(1) of the Directive, since the supplementary interpretation of the contract gets around the Community law prohibition of the validity-preserving reduction, see H.-W. Micklitz and N. Reich, 'Luxemburg ante portas - jetzt auch im deutschen "runderneuerten” AGB-Recht?', in W. Wurmnest et al (eds), Festschrift für Ulrich Magnus (forthcoming 2014). 


\section{h) Obligation on the national court to invite the parties to submit their observa- tions on its finding of an unfair term (Case C-472/11 Banif Plus Bank)}

\section{aa) Facts}

The Hungarian Fővárosi Biróság asked the CJEU whether Articles 6(1) and 7(1) of the Directive must be interpreted as precluding or, on the contrary, allowing the national court which has held, of its own motion, that a contractual term is unfair to inform the parties that it has found that there are grounds for invalidity and to invite them to submit a statement in that regard. It also asked whether, when examining an unfair contract term, it is permissible for the court to examine all the terms of the contract, or only the terms on which the party concluding the contract with the consumer bases his claim.

The consumer ceased fulfilling his obligation to make repayments under his credit agreement, whereupon the Banif Plus Bank terminated the contract. The pre-formulated credit agreement provided that, if that agreement were to be terminated early due to breach of contract by the borrower, the borrower would be obliged to pay the sum total of all outstanding instalments, default interest and costs. The instalments payable included interest on the transaction and an insurance fee, in addition to the capital amount. The Pesti Központi kerületi bíróság, in its capacity as a court of first instance, informed the parties that it took the view that the clause was unfair and invited the parties to comment on that matter. The court ordered the consumer to pay the amount that was calculated without application of the disputed clause. The Banif Plus Bank appealed against that decision.

\section{bb) Main reasoning}

The full effectiveness of the protection provided for by the Directive requires that 'the national court which has found of its own motion that a term is unfair should be able to establish all the consequences of that finding, without waiting for the consumer, who has been fully informed of his rights, to submit a statement requesting that that term be declared invalid." ${ }^{89}$ However, the national court must take into account the requirements of effective judicial protection under Article 47 of the Charter of Fundamental Rights of the European Union. These requirements include the principle of audi alteram partem. The national court is, following an assessment made of its own motion that that term is unfair, as a 'general rule'

89 Case 472/11 Banif Plus Bank Zrt v Csaba Csipai and Viktória Csipai 21.2.2013 (CJEU), paragraph 28. 
required to inform the parties to the dispute of that fact and to invite each of them to set out their views on that matter, with the opportunity to challenge the views of the other party, in accordance with the formal requirements laid down in that regard by the national rules of procedure..$^{90}$ As Asturcom Telecomunicaciones ${ }^{91}$ highlighted, this principle must be applied by taking into account, inter alia, the basic principles of the domestic judicial system..$^{92}$ The national court may, where appropriate, take into account the will of the consumer when, conscious of the non-binding nature of an unfair term, that consumer states nevertheless that he is opposed to that term being disregarded, thus giving his free and informed consent to the term in question. ${ }^{93}$ Regarding the second question, the CJEU refers to Article 3(1) and Article 4(1) of the Directive and states that the national court must take account of all of the other terms of the contract in order to determine the unfairness of the contractual term on which the claim is based. ${ }^{94}$

\section{cc) Integration in the case-law}

With regard to its case-law in Pannon $G S M,{ }^{95}$ the CJEU clarified that the national court is not only entitled, but is obliged, to inform the consumer of the unfairness of the clause and, where appropriate, to take into account the will of the consumer to apply the unfair clause. The reference in paragraph 24 to VB Pénzügyi Lizing, ${ }^{96}$ whereby the national court must investigate of its own motion whether a term falls within the scope of the Directive, suggests that this obligation applies not only to clauses that confer territorial jurisdiction, but also to clauses on the substantive nature of the contract. In VB Pénzügyi Lizing, on the basis of the national procedural autonomy, Advocate-General Trstenjak had refused to set aside the evidential principle, according to which it is up to the parties to submit all the relevant facts. ${ }^{97}$

90 Case 472/11, n 89 above, paragraphs 29-31. Referring to its case-law in case 89/08 P Commission v Ireland and Others [2009] ECR I-11245 (CJEU), paragraphs 50, 54.

91 Case 40/08, n 16 above, paragraph 39.

92 Case 472/11, n 89 above, paragraph 33.

93 Case 472/11, n 89 above, paragraph 35.

94 Case 472/11, n 89 above, paragraphs 40, 41.

95 Case 243/08, n 2 above, paragraph 33.

96 Case 137/08, n 41 above, paragraph 56.

97 AG Trstenjak, n 46 above, paragraphs 109 et seq. 


\section{i) Possibilities for legal protection in mortgage enforcement proceedings; Cri- teria for assessing unfairness (Case C-415/11 Aziz)}

\section{aa) Facts}

The Spanish Juzgado de lo Mercantil no 3 de Barcelona asked the CJEU about the compatibility of the Spanish mortgage enforcement proceedings with Directive 93/13/EEC. According to the Spanish Civil Procedure Code, the debtor may not object to the unfairness of a term of the loan agreement in the mortgage enforcement proceedings. An objection to an unfair term is only possible in separate declaratory proceedings which do not lead to a suspension of the enforcement proceedings. The Spanish court also asked for the criteria for assessing the fairness of three specific clauses concerning acceleration in long-term contracts, setting of default interest rates, and the agreement on quantification.

In the case at hand a consumer concluded a loan agreement with the defendant bank in order to finance his own home and created a mortgage to secure that loan. The immovable property subject to the mortgage was the consumer's family home. The consumer stopped making payments and, having called in vain upon him to pay, the bank instituted enforcement proceedings of the notarial instrument attesting the debt against him before the Juzgado de Primera Instancia $\mathrm{n}^{\circ} 5$ de Martorell. After completion of the enforcement proceedings, the consumer applied to the Juzgado de lo Mercantil $\mathrm{n}^{\circ} 3$ de Barcelona for a declaration seeking the annulment of a clause of the mortgage loan agreement, on the ground that it was unfair and, accordingly, of the enforcement proceedings.

\section{bb) Main reasoning}

The national mechanisms for enforcement and the rules implementing the grounds of objection allowed in mortgage enforcement proceedings are subject to the Member States' procedural autonomy, limited by the principles of equivalence and effectiveness. ${ }^{98}$ In the Spanish procedural law, the final vesting of mortgaged property in a third party is always irreversible, even if the unfairness of the term results in the annulment of the mortgage enforcement proceedings, except where that consumer made a preliminary registration of the application for annulment of the mortgage before the marginal note regarding issue of the security certificate. ${ }^{99}$ However, there is a significant risk that the consumer will not make that

98 Case 415/11 Mohamed Aziz v Caixa d'Estalvis de Catalunya, Tarragona i Manresa (Catalunyacaixa) 14.3.2013 (CJEU), paragraph 50.

99 Case 415/11, n 98 above, paragraphs 54-57. 
preliminary registration within the period prescribed for that purpose, 'either because of the rapidity of the enforcement proceedings in question or because he is unaware of or does not appreciate the extent of his rights. ${ }^{100}$ If enforcement in respect of the mortgaged immovable property took place before the judgment of the court in the declaratory proceedings declaring unfair the contractual term on which the mortgage is based and annulling the enforcement proceedings, that judgment would enable that consumer to obtain only subsequent protection of a purely compensatory nature. This would be incomplete and insufficient and would not constitute either an adequate or effective means of preventing the continued use of that term, contrary to Article 7(1). ${ }^{101}$ The CJEU considers the Spanish legislation to infringe the principle of effectiveness, especially because that means of consumer protection is limited to payment of damages and interest and does not make it possible to prevent the definitive and irreversible loss of the consumer's dwelling. ${ }^{102}$ Advocate-General Kokott's opinion concluded that the principle of effectiveness requires that the court hearing the declaratory proceedings has the possibility of staying the enforcement proceedings (provisionally) in order to stop enforcement until it has been assessed whether a term is unfair..$^{103}$ The CJEU, referring to Unibet, ${ }^{104}$ confirmed the view of the Advocate-General. ${ }^{105}$

In order to ascertain whether a term causes a 'significant imbalance' in the parties' rights and obligations arising under the contract, to the detriment of the consumer, it must in particular be considered what rules of national law would apply in the absence of an agreement by the parties in that regard. ${ }^{106}$ Such an imbalance arises 'contrary to the requirement of good faith', if the seller or supplier, dealing fairly and equitably with the consumer, could not reasonably assume that the consumer would have agreed to such a term in individual contract negotiations. ${ }^{107}$ Referring to the opinion of Advocate-General Kokott, the CJEU explained the evaluation criteria for the specific clauses of the mortgage loan agreement:

Regarding the term concerning acceleration, in long-term contracts, on account of events of default occurring within a limited specific period, it held that

100 Case 415/11, n 98 above, paragraph 58.

101 Case 415/11, n 98 above, paragraph 60.

102 Case 415/11, n 98 above, paragraph 61.

103 AG Kokott, opinion of 8.11.2012 - case 415/11, n 98 above, paragraph 57.

104 Case 432/05 Unibet (London) Ltd and Unibet (International) Ltd v Justitiekansler [2007] ECR I-2271, paragraph 77 .

105 Case 415/11, n 98 above, paragraph 59.

106 Case 415/11, n 98 above, paragraph 68.

107 Case 415/11, n 98 above, paragraph 69. 
the national court must assess 'whether the right of the seller or supplier to call in the totality of the loan is conditional upon the non-compliance by the consumer with an obligation which is of essential importance in the context of the contractual relationship in question, whether that right is provided for in cases in which such non-compliance is sufficiently serious in the light of the term and amount of the loan, whether that right derogates from the relevant applicable rules and whether national law provides for adequate and effective means enabling the consumer subject to such a term to remedy the effects of the loan being called in'. ${ }^{108}$

Regarding the term concerning the fixing of default interest, the CJEU held that in light of point 1(e) of the Annex to the Directive, in conjunction with Articles 3(1) and 4(1), the national court must assess, 'first, the rules of national law which would apply to the relationship between the parties, in the event of no agreement having been reached in the contract in question or in other consumer contracts of that type and, second, the rate of default interest laid down, compared with the statutory interest rate, in order to determine whether it is appropriate for securing the attainment of the objectives pursued by it in the Member State concerned and does not go beyond what is necessary to achieve them'.$^{109}$

Regarding the term concerning the unilateral determination by the lender of the amount of the unpaid debt, the CJEU held that taking into account point 1(q) of the Annex to the Directive and the criteria contained in Articles 3(1) and 4(1) thereof, the referring court must assess whether and, if appropriate, to what extent 'the term in question derogates from the rules applicable in the absence of agreement between the parties, so as to make it more difficult for the consumer, given the procedural means at his disposal, to take legal action and exercise rights of the defence'. ${ }^{110}$

\section{cc) Integration in the case-law}

In $A z i z$ the CJEU encountered the social implications of the euro crisis. Neither the Advocate-General nor the Court speak of the right to housing in accordance with Article 34(3) of the Charter of Fundamental Rights explicitly, although it repeatedly appears in the reasoning. Aziz affects not only the Spanish consumers. This

108 Case 415/11, n 98 above, paragraph 73; with reference to AG Kokott, n 103 above, paragraphs $77,78$.

109 Case 415/11, n 98 above, paragraph 74; with reference to AG Kokott, n 103 above, paragraphs $85-87$.

110 Case 415/11, n 98 above, paragraph 75; the CJEU does not refer to the opinion of the Advocate-General, who establishes more detailed criteria for the assessment; see AG Kokott, n 103 above, paragraphs 89-95. 
is a classic case of a 'public interest litigation'. The CJEU occurs as a political actor, who uses the law to compensate for the negative effects of the euro crisis. ${ }^{111}$

In Aziz, the CJEU did not take on the question whether the consumer in the context of enforcement proceedings needs to have the opportunity to raise the unfairness of clauses. However, it goes into the matter to the relationship between mortgage enforcement procedures and declaratory proceedings. ${ }^{112}$ The CJEU established a new remedy, which connects the enforcement proceedings with the declaratory proceedings. The court in the declaratory proceedings must have the power to order an interim stay of the enforcement proceedings. The case differs from VB Pénzügyi Lízing ${ }^{113}$ and Banco Español de Crédito, ${ }^{114}$ which dealt with the duties of national courts to carry out an assessment of the unfairness of contract terms of their own motion. ${ }^{115}$ Nevertheless, the question of the courts' assessment of the unfairness of contract terms of its own motion remained open in Aziz. How can it be ensured that the consumer receives the protection of his rights despite being ignorant of the unfair term? ${ }^{116}$

In Aziz, the CJEU confirmed that it had found a middle ground between a comprehensive control competence in Océano Grupo $^{117}$ and the lack of control competence as in Freiburger Kommunalbauten. ${ }^{118}$ The CJEU has gradually concretized the abstract criteria to be used for assessing clauses and clearly restricts the scope of the national courts. In Aziz, the CJEU interpreted for the first time the criterion of 'imbalance' and the requirement of 'good faith'. The CJEU gives the dispositive law a model function within the assessment of terms. ${ }^{119}$ AdvocateGeneral Kokott and the CJEU reject an abstract and general substantive control and require instead a concrete assessment based on the circumstances of the case. ${ }^{120}$ The CJEU points to subjective criteria: whether the consumer had consented to the clause in individual negotiations and whether the trader, dealing fairly and equitably, could reasonably assume that the consumer would have agreed to a particular term. The CJEU does not address the relationship of the

111 H.-W. Micklitz, 'Theme VIII. Unfair Contract Terms - Public Interest Litigation before European Courts', in E. Terryn, G. Straetmans and V. Colaert (eds), Landmark Cases of EU Consumer Law - In honour of Jules Stuyck (Antwerp: Intersentia, 2013) 633.

112 Case 415/11, n 98 above, paragraphs 37-39.

113 Case 137/08, n 41 above.

114 Case 618/10, n 78 above.

115 Case 415/11, n 98 above, paragraph 49.

116 Micklitz, n 111 above.

117 Joined cases 240/98 to 244/98, n 7 above.

118 Case 237/02, n 8 above.

119 M. Ebers, case note, (2013) 5 LMK Anmerkung, 345483.

120 Micklitz, n 111 above. 
requirement of 'good faith' to the criterion of 'imbalance'. ${ }^{121}$ In line with the utilisation of the Annex in VB Pénzügyi Lízing ${ }^{122}$ and Invitel, ${ }^{123}$ the CJEU also uses the Annex in Aziz to concretise the criteria for the assessment of terms. ${ }^{124}$

\section{j) Assessment of price increase terms in gas supply contracts; Transparency as information requirement (Case C-92/11 RWE Vertrieb)}

\section{aa) Facts}

The German Bundesgerichtshof asked whether Article 1(2) of Directive 93/13/EEC is to be interpreted as meaning that contractual terms concerning price variations in gas supply contracts with consumers who are to be supplied outside the general obligation to supply gas are not subject to the provisions of the Directive if, in those contractual terms, the statutory provisions which apply to standard tariff customers within the framework of the general obligation to provide gas (AVBGasV) are incorporated unchanged. In addition, the German Federal Court of Justice sought clarification as to whether, in light of Articles 3 and 5 of Directive 93/13/EEC in conjunction with point 1(j) and 2(b) of the Annex thereof and Article 3(3) of Directive 2003/55 in conjunction with points (b) and/or (c) of Annex A thereof, contractual terms meet the requirements for plain and intelligible wording and transparency if, although the grounds, conditions and scope of a change in price are not set out, the gas supply company informs its customers of every price increase in good time in advance and customers have the right to terminate the contract.

In the national proceedings, a consumer organisation, under rights assigned by 25 consumers, claimed from the energy supply undertaking RWE reimbursement of the additional amounts paid to it by those consumers following price increases. RWE had made the price increases in the years 2003 to 2005 based on contractual gas price change clauses that refer to or contain provisions identical to the national legal regulation of obligatory gas supply. The legislation allowed the supplier to vary gas prices unilaterally without stating the grounds, conditions or scope of the variation, while ensuring, however, that customers would be informed of the variation and would if appropriate be free to terminate the contract. However, the national legislation, did not apply to those special contracts and governed standard tariff contracts only.

121 Ebers, n 119 above.

122 Case 137/08, n 41 above.

123 Case 472/10, n 63 above.

124 Micklitz, n 111 above. 


\section{bb) Main reasoning}

The exclusion in Article 1(2) of Directive 93/13/EEC of contractual clauses which are based on 'mandatory statutory or regulatory provisions' is justified by the fact that it may legitimately be supposed that the national legislature struck a balance between all the rights and obligations of the parties to certain contracts. ${ }^{125} \mathrm{An}$ intention of the parties to extend the application of those rules to a different contract cannot be equated to the establishment by the national legislature of a balance between all the rights and obligations of the parties to the contract. ${ }^{126}$ Otherwise, a supplier could easily avoid review of the unfairness of terms not individually negotiated with a consumer by drafting the terms in his contracts in the same way as those laid down by national legislation for certain categories of contracts. ${ }^{127}$ The German legislature chose to exclude the special contracts from the scope of the AVBGasV. ${ }^{128}$ In accordance with the views of the Commission and Advocate-General Trstenjak, Directive 93/13/EEC applies to general terms and conditions, incorporated into contracts concluded between a supplier and a consumer, which reproduce a rule of national law applicable to another category of contracts. ${ }^{129}$

Although in Directives 93/13/EEC and 2003/55/EC the European legislature recognised, in the context of contracts of indeterminate length such as contracts for the supply of gas, the existence of a legitimate interest of the supplier in being able to alter the charge for its service, a high level of consumer protection must be ensured. ${ }^{130}$ To assess whether the gas price variation clause meets the requirements in Article 3 and Article 5 of Directive 93/13/EEC, it must be examined in terms of Invitel ${ }^{131}$ especially, 'whether the contract sets out in transparent fashion the reason for and method of the variation of the charges for the service to be provided, so that the consumer can foresee, on the basis of clear, intelligible criteria, the alterations that may be made to those charges and, secondly, whether consumers have the right to terminate the contract if the charges are in fact altered'. ${ }^{132}$ The lack of information on the point before the contract is concluded cannot, in principle, be compensated for by the mere fact that consumers will,

125 Case 92/11 RWE Vertrieb AG v Verbraucherzentrale Nordrhein-Westfalen eV 21.3.2013 (CJEU), paragraph 28.

126 Case 92/11, n 125 above, paragraph 29.

127 Case 92/11, n 125 above, paragraph 31.

128 Case 92/11, n 125 above, paragraphs 33-37.

129 Case 92/11, n 125 above, paragraphs 38, 39.

130 Case 92/11, n 125 above, paragraphs 45-47.

131 Case 472/10, n 63 above, paragraph 30.

132 Case 92/11, n 125 above, paragraph 49. 
during the performance of the contract, be informed in good time of a variation of the charges and of their right to terminate the contract. ${ }^{133}$ It is of fundamental importance that the right of termination given to the consumer is not purely formal but can actually be exercised. ${ }^{134}$ This amounts to a balancing of the interests of the two parties, because '[t]o the supplier's legitimate interest in guarding against a change of circumstances there corresponds the consumer's equally legitimate interest, first, in knowing and thus being able to foresee the consequences which such a change might in future have for him and, secondly, in having the data available in such a case to allow him to react most appropriately to his new situation' ${ }^{135}$ It is for the national court to carry out the assessment of the gas price variation clause with regard to all the circumstances of the particular case, including all the general terms and conditions of the consumer contracts of which the term at issue forms part. ${ }^{136}$ At the request of the German Government and RWE to limit the temporal effect of the judgment, the CJEU refers to two essential criteria that must be fulfilled before such a limitation can be imposed, namely that those concerned have acted in good faith and that there is a risk of serious difficulties. ${ }^{137}$

\section{cc) Integration in the case-law}

The CJEU is getting further away from the declaration in Freiburger Kommunalbauten $^{138}$ that the question of invalidity is not the competence of the CJEU but of the national court. The detailed interpretation of the requirements in Article 3 and Article 5 of Directive 93/13/EEC allows the national court little room not to discard the gas price variation clause. ${ }^{139}$ The originally individualistic control of unfair terms is turning into a Union specific market control. ${ }^{140}$ The CJEU turns the transparency requirement into a positive information obligation as only clear and transparent information allows the consumer to make use of his rights. ${ }^{141}$ On 31.07.2013 the German Federal Court of Justice held, in the subsequent decision,

133 Case 92/11, n 125 above, paragraph 51.

134 Case 92/11, n 125 above, paragraph 54.

135 Case 92/11, n 125 above, paragraph 53.

136 Case 92/11, n 125 above, paragraph 55.

137 Case 92/11, n 125 above, paragraphs 59-62.

138 Case 237/02, n 8 above.

139 N. Reich and H.-W. Micklitz, 'Von der Klausel- zur Marktkontrolle' (2013) 12 Europäische Zeitschrift für Wirtschaftsrecht 457, 459.

140 Reich and Micklitz, n 139 above, 457.

141 Reich and Micklitz, n 139 above, 460. For a recent review of German courts' approach to unilateral price variations by gas supply undertakings, see: P. Rott, 'The Adjustment of Long- 
that the price variation clauses used by RWE in special contracts that adopt, or refer to, the rules contained in the AVBGasV are invalid. ${ }^{142} \mathrm{~A}$ collective system for the settlement of recoveries would simplify the rescission. The case law of the CJEU is moving gradually towards that goal. ${ }^{143}$

\section{k) Application of Directive 93/13/EEC to a residential tenancy agreement; judicial power to mitigate unfair terms (Case C-488/11 Asbeek Brusse and de Man Garabito)}

\section{aa) Facts}

The Gerechtshof te Amsterdam asked the CJEU whether a tenancy agreement between a person who leases out residential premises on a commercial basis and a person who rents such premises on a non-commercial basis falls within the scope of Directive 93/13/EEC. Also, it asked whether the fact that the provisions of the Directive are of equal standing to national rules of public policy means that the national court is obliged to assess of its own motion a contractual term and to find that term to be void if it is unfair. In its third question, the national court wanted to know whether it is compatible with Article 6 that the national court does not refrain from applying an unfair contractual penalty clause but merely mitigates the amount of the penalty instead.

In the case at hand, a company letting residential property on a commercial basis rented premises to a couple who were acting on a non-commercial basis. The terms and conditions of the lease stipulated that the tenant has to pay a penalty in case of late payment. Since the tenant did not comply with their payments, they were sued before the Rechtbank Alkmaar. The tenants appealed and requested that the amounts granted by way of penalties were reduced, having regard to the discrepancy between, on the one hand, those sums, and, on the other, the detriment suffered by the landlord.

\section{bb) Main reasoning}

The Directive is applicable to a tenancy agreement between a person who lets residential premises on a commercial basis and a person who rents such premises on a non-commercial basis. The European legislature's intention was not to

Term Supply Contracts: Experience from German Gas Price Case Law' (2013) 3 European Review of Private Law 717.

142 VIII ZR 162/09.

143 Reich and Micklitz, n 139 above, 460, and more in depth, Micklitz and Reich, n 88 above. 
restrict the scope of the Directive solely to contracts concluded between a seller and a consumer. ${ }^{144}$ The tenth recital in the preamble to the Directive clearly indicates that the uniform rules of law in the matter of unfair terms should apply to 'all contracts' concluded between sellers or suppliers and consumers, as defined in Article 2(b) and (c) of the directive. ${ }^{145}$ The decisive factor is whether the parties are acting for purposes relating to their trade, business or profession. ${ }^{146}$ Consumer protection is of special importance in a tenancy agreement. The inequality between the parties is aggravated by 'the fact that, from an economic perspective, such a contract relates to an essential need of the consumer, namely to obtain lodging, and involves sums which most frequently, for the tenant, represent one of the most significant items in his budget, while, from a legal perspective, this is a contract which, as a general rule, is covered by complex national rules about which individuals are often poorly informed.' ${ }^{147}$

Due to lack of Union legislation in the area, the CJEU noted that the procedural rules governing appeal proceedings seeking to safeguard the rights that individuals derive from European Union law fall within the internal legal order of the Member States by virtue of the principle of national procedural autonomy. ${ }^{148}$ According to the principle of equivalence, where the national court has the power to examine of its own motion the validity of a legal measure in the light of national rules of public policy, it must also exercise that power in the light of the criteria laid down in the Directive to decide whether a contractual term may be unfair. ${ }^{149}$ It follows that, where the national court has the power to annul of its own motion a term which is contrary to public policy or a mandatory statutory provision, it must also annul of its own motion a contractual term which is unfair under the Directive. ${ }^{150}$ However, the national court must inform the parties to the dispute of the finding of unfairness and invite each of them to set out its views on that matter, with the opportunity to challenge the views of the other party. ${ }^{151}$

Point 1(e) of the Annex to the Directive mentions, among the terms which may be declared unfair within the meaning of the Directive, terms which have the object or effect of requiring any consumer who fails to fulfil his obligation to pay a

144 Case 488/11 Dirk Frederik Asbeek Brusse and Katarina de Man Garabito v Jahani BV 30.5.2013 (CJEU), paragraph 28.

145 Case 488/11, n 144 above, paragraph 29.

146 Case 488/11, n 144 above, paragraph 30.

147 Case 488/11, n 144 above, paragraph 32.

148 Case 488/11, n 144 above, paragraph 42.

149 Case 488/11, n 144 above, paragraph 45.

150 Case 488/11, n 144 above, paragraph 51.

151 Case 488/11, n 144 above, paragraph 52. 
disproportionately high sum in compensation. As highlighted in Invitel ${ }^{152}$ the content of the Annex is an 'essential element' on which the competent court may base its assessment as to the unfair nature of that term. ${ }^{153}$ Referring to its case-law in Banco Español de Crédito ${ }^{154}$ the CJEU emphasizes that under Article 6(1) national courts are required to exclude the application of an unfair contractual term, without being authorised to revise the content of that term. ${ }^{155}$

\section{cc) Integration in the case-law}

The CJEU affirmed the application of Directive 93/13/EEC to pre-formulated tenancy agreements between a commercial landlord and a non-commercial tenant. The Dutch version of Article 1(1) sets out that the purpose of the Directive is to harmonize national rules on unfair terms in contracts concluded between a 'seller' ('verkoper') and a consumer. Most other language versions use an expression which is wider in scope to designate the other party to the contract with the consumer. The English version uses the terms 'seller or supplier'. ${ }^{156}$ In addition, the CJEU confirmed its ruling in Banco Español de Crédito. It declared the mitigation of an excessive penalty based on an unfair contractual clause under Dutch law to be incompatible with Article 6(1) of Directive 93/13/EEC.

\section{l) The national court's obligation to examine, of its own motion, whether a contractual term is unfair in appeal proceedings (Case C-397/11 Jörös)}

\section{aa) Facts}

The Hungarian Fővárosi Bíróság asked the CJEU whether a national court, before which appeal proceedings have been brought concerning the validity of terms in a contract concluded between a seller or supplier and a consumer, is entitled to examine the unfair nature of the terms at issue if that ground for invalidity was not raised in the proceedings at first instance and new facts or evidence cannot generally be taken into consideration in appeal proceedings under national law.

The consumer concluded a credit contract with a Hungarian financial institution. The consumer argued that the credit contract was partially invalid, but did not refer to the unfairness of a contractual term. The court of first instance

152 Case 472/10, n 63 above, paragraph 26.

153 Case 488/11, n 144 above, paragraph 55.

154 Case 618/10, n 78 above, paragraphs 65-69.

155 Case 488/11, n 144 above, paragraphs 57-59.

156 Case 488/11, n 144 above, paragraph 25. 
dismissed the action. The consumer lodged an appeal against the judgment and claimed that certain clauses of the credit contract were invalid as they were manifestly contrary to ethical practice in that they allowed the creditor unilaterally to amend the contract terms and obliged the debtor to bear the burden of the consequences of those amendments.

\section{bb) Main reasoning}

Based on the principle of procedural autonomy, it is for the Member States to lay down the procedural rules governing appeal proceedings for safeguarding the rights that individuals derive from European Union law. ${ }^{157}$ According to the principle of equivalence, where the national court ruling in appeal proceedings has a discretion or the obligation to examine of its own motion the validity of a legal measure in the light of national rules of public policy, even though no conflict in that area was raised at first instance, it must also exercise such a power for the purposes of assessing, of its own motion, in the light of the criteria in Directive 93/13, whether a contractual term falling within the scope of application of that Directive is unfair. ${ }^{158}$ The Hungarian procedural law complies with the principle of effectiveness, in so far that a court ruling in appeal proceedings has jurisdiction, as soon as it has available to it the legal or factual elements necessary for that task, to assess, of its own motion or by redefining the legal basis of the application, whether those elements point to grounds for invalidity of a contractual term, even where the party to the proceedings which could have argued that the term was invalid on the basis of those elements did not do so. ${ }^{159}$

As noted already in Banif Plus Bank, ${ }^{160}$ the national court is required, without waiting for a request of the consumer, to establish all the consequences, arising under national law, of a finding that the term in question is unfair in order to ensure that the consumer is not bound by that term. ${ }^{161}$ As national law must be interpreted in accordance with Directive 93/13 so that the rights of consumers are effectively protected, it follows that national courts must apply, as far as possible, their internal procedural rules in such a way as to achieve the result laid down by Article 6(1) of the Directive. ${ }^{162}$ To assess whether the contract actually can exist without the clause in question, objective criteria are, in principle, decisive.

157 Case 397/11 Erika Jörös v Aegon Magyarország Hitel Zrt 30.5.2013 (CJEU), paragraph 29.

158 Case 397/11, n 157 above, paragraph 30.

159 Case 397/11, n 157 above, paragraphs 35, 37.

160 Case 472/11, n 89 above, paragraphs 27, 28.

161 Case 397/11, n 157 above, paragraphs 41, 42.

162 Case 397/11, n 157 above, paragraph 51. 
According to Pereničova ${ }^{163}$ there is the possibility of declaring a consumer contract containing one or more unfair terms invalid as a whole where that will ensure better protection of the consumer. ${ }^{164}$

\section{cc) Integration in the case-law}

Gradually the case-law approaches the problem of what exactly the legal consequences of Article 6 should be. The Directive says that unfair terms shall 'not be binding' on consumers. This category should only arise in a few cases. Clauses can be ineffective, in part or in whole, or void. The Hungarian court here obviously wanted to clarify this, but it has not been achieved. Sooner or later, the CJEU should also respond to this set of questions.

\section{m) Territorial jurisdiction for an action for an injunction brought by a regional consumer protection association (Case C-413/12 Asociación de Consumidores Independientes de Castilla y León)}

\section{aa) Facts}

The reference for a preliminary ruling from the Spanish Audiencia Provincial de Salamanca concerned the question, whether EU law precludes national procedural rules under which an action for an injunction initiated by a consumer protection association must be brought before the courts where the defendant is established or has its address and whereby no appeal lies against a decision declining territorial jurisdiction.

The Asociación de Consumidores Independientes de Castilla y León (ACICL) is a regional consumer protection association, whose remit is limited to the territory Castile-León and who has its registered office in Salamanca. ACICL brought an action for an injunction against a company having its registered office in Barcelona before the first instance court in Salamanca. It sought to prevent the continued use of certain alleged unfair terms of the general conditions governing the use of that company's website. The first instance court declined its jurisdiction on the ground that Spanish procedural law confers jurisdiction to hear actions for injunctions brought to protect the consumers' collective interest to the court where the defendant is established or has its address. Although the Spanish procedural rules do not provide for such a remedy, ACICL brought an appeal

163 Case 453/10, n 50 above, paragraph 35.

164 Case 397/11, n 157 above, paragraph 47. 
before the Audiencia Provincial de Salamanca against the decision declining jurisdiction.

\section{bb) Main reasoning}

As EU law does not lay down rules attributing territorial jurisdiction for actions for an injunction for the protection of the consumers' interest or regulating the number of instances of jurisdiction in relation to decisions declining territorial jurisdiction in such circumstances, the CJEU held that those rules are governed by the principle of procedural autonomy to the extent that they comply with the principles of equivalence and effectiveness. ${ }^{165}$ The CJEU did not find any evidence for a breach of the principle of equivalence and concluded in line with the opinion of Advocate-General Mengozzi that the Spanish procedural rules comply with the principle of effectiveness. The particular financial situation of ACICL, which may render it impossible for ACICL to initiate an action before the court where the defendant has its registered office, is irrelevant. The general interest in the sound administration of justice and foreseeability prevails over the individual interest. ${ }^{166}$ The CJEU grounds its decision on four specific aspects of the Spanish procedural system: Firstly, the court designated by the court which declined jurisdiction may not question its own territorial jurisdiction. ${ }^{167}$ Secondly, ACICL is not required to be present before court at all stages of the proceedings. ${ }^{168}$ Thirdly, the financial difficulties of ACICL may be overcome by other mechanisms as legal aid or a waiver of security. ${ }^{169}$ Fourthly, the Spanish procedural rules aim to avoid contradictory judicial rulings and thereby contribute to legal certainty. ${ }^{170}$

In response to the submission by the Spanish court, the CJEU made clear that its interpretation of the Brussels Convention in Henkel, ${ }^{171}$ where it found that the efficacy for actions for an injunction under Article 7 of Directive 93/13 would be considerably diminished if those actions could be brought only in the State where the trader is domiciled, applies only in the cross-border context and cannot be transposed to the circumstances at hand. ${ }^{172}$ The CJEU also rejected to extend the

165 Case 413/12 Asociación de Consumidores Independientes de Castilla y León v Anuntis Segundamano España SL 5.12.2013 (CJEU), paragraphs 28-30.

166 Case 413/12, n 165 above, paragraphs 37 and 38.

167 Case 413/12, n 165 above, paragraph 40.

168 Case 413/12, n 165 above, paragraph 41.

169 Case 413/12, n 165 above, paragraphs 42 and 43.

170 Case 413/12, n 165 above, paragraph 45.

171 Case 167/00 Verein für Konsumenteninformation v Karl Heinz Henkel [2002] ECR I-08111 (CJEU), paragraph 43.

172 Case 413/12, n 165 above, paragraphs 46 and 47. 
preferential procedural treatment granted to individual consumers to consumer associations for the purpose of Directive 93/13: An action for an injunction initiated by a consumer protection association is not characterized by the same imbalance that is present in an individual action brought by a consumer against a seller or supplier. ${ }^{173}$

\section{cc) Integration in the case-law}

In Asociación de Consumidores Independientes de Castilla y León, the CJEU deprived consumer protection associations of the possibility to initiate actions for an injunction at the place of their main office. The CJEU followed AdvocateGeneral Mengozzi in drawing a clear distinction between individual cases, where the consumer is the weaker party and has to be protected, and collective actions initiated by consumer protection associations, where no need for protection exists. This distinction is debatable as consumer protection associations often do not have the same level of resources and competence as businesses. The answer of the CJEU could be different if the procedure was a cross-border one.

\section{n) Compatibility of an out-of-court settlement procedure of a secured claim by recourse to the public auction of immovable property with Directive 93/13/ EEC (Case C-482/12 Macinský and Macinská)}

\section{aa) Facts}

The Slovak Okresný súd Prešov asked the CJEU whether the Slovak rules enabling a creditor to enforce a secured claim based on an unfair term in a consumer contract through the sale of immovable property by means of an out-of-court procedure are compatible with Directive 93/13/EEC.

Mr and Mrs Macinský took out a loan secured by a property interest over their home from Financreal s $\mathrm{r}$ o. When the debtors failed to pay the monthly instalments, Financreal decided to take action against them and ceded its claim to Getfin s $r$ o, a debit recovery business. Getfin brought legal proceedings against the debtors before the Okresný súd Prešov and engaged a private undertaking to proceed with the enforcement of the security interest by extra-judicial means through the sale of the apartment by public auction. The debtors successfully applied to the Okresný súd Prešov for interim relief in order to suspend the out-ofcourt enforcement proceedings. In the legal proceedings initiated by Getfin, the

173 Case 413/12, n 165 above, paragraphs 48-50. 
Okresný súd Prešov came to the conclusion that the interest rate specified in the contract is morally unacceptable and, accordingly, the contract null and void. In connection with the proceedings for interim relief, the Slovak court decided to make a preliminary reference to the CJEU.

\section{bb) Opinion of Advocate-General Wahl}

Advocate-General Wahl considers that the question referred by the Slovak court ought not to be admissible, as the answer will not have any impact on the outcome of the case before the national court. The order of reference states that the company which was engaged in order to enforce the claim has abandoned the pursuit of a public auction. In addition, the judgment of the Slovak court, which held that the loan agreement is null and void, has become final. The loan agreement provides therefore no longer a legal basis for the procedure at issue. ${ }^{174}$ However, to anticipate the possibility that the CJEU might come to a different conclusion, Advocate-General Wahl examined the substantive question of the Slovak court.

Advocate-General Wahl concluded that the national procedure at issue provides to a sufficient degree for the effective protection of the rights of consumers as required under Directive 93/13. ${ }^{175} \mathrm{He}$ distilled from the case-law of the CJEU in Banco Español de Crédito and Aziz that providing traders with recourse to a special procedure is only in so far contrary to the principle of effectiveness as it makes it in practice impossible or excessively difficult to apply the protection which Directive 93/13 intends to confer on consumers. ${ }^{176}$ While the national procedural rules must provide certain guarantees in order to protect the weaker party, Advocate-General Wahl did not consider it excessive to require consumers to initiate legal proceedings against the trader to suspend or halt the out-of-court enforcement procedure in the form of a public auction. ${ }^{177}$

The specificities of the Slovak procedural and remedial system comply with the principle of effectiveness. Before the public auction will take place, the debtor is given at least 30 days from his notification to challenge the enforcement procedure. After the sale of the property has taken place, the debtor has up to three months to challenge the public auction. While the law obliges the debtor to surrender the property after the sale without undue delay, the debtor can request

174 AG Wahl, opinion of 21.11.2013 - case 482/12 Peter Macinský, Eva Macinská v Getfin s r o, Financreal s ro, paragraph 42.

175 AG Wahl, n 174 above, paragraph 64.

176 AG Wahl, n 174 above, paragraph 68.

177 AG Wahl, n 174 above, paragraphs 69, 78. 
a court to suspend the procedure and the surrender of the property. Moreover, in the case where the consumer has in fact surrendered his property, there is a possibility of recovering that property if the public auction is annulled. ${ }^{178}$ Advocate-General Wahl stresses that once a consumer has challenged a sale by public auction, that challenge triggers the case-law of the CJEU on the responsibilities of the national court to assess of its own motion whether a term is unfair and to ensure that the consumer is not bound by an unfair term. ${ }^{179}$

\section{cc) Integration in the case-law}

As pointed out by Advocate-General Wahl, the Court must address an issue, which it did not explicitly rule upon in Banco Español de Crédito ${ }^{180}$ or Aziz, ${ }^{181}$ namely whether it is compatible with Directive 93/13 for a Member State to require consumers to make the first move to suspend or halt the enforcement of a contract which allegedly contains an unfair term. It remains to be seen whether the CJEU will follow the Advocate-General in confirming this question. What is amazing in this opinion is the tone and the language in which the Advocate-General criticizes the intransparency and incomprehensibility of the Slovak legal system.

\section{o) The right of consumer protection associations to intervene in enforcement proceedings of an arbitration award (Case C-470/12 Pohotovost')}

\section{aa) Facts}

The Slovak Okresný súd Svidník asked the CJEU whether Directive 93/13 and Articles 47 and 38 of the Charter of Fundamental Rights of the European Union require or preclude granting consumer protection associations leave to intervene in enforcement proceedings.

The Slovak consumer protection association HOOS applied to intervene in the enforcement proceedings of an arbitration award against Mr Vašuta. The legal proceedings arose out of the consumer credit agreement, which Mr Vašuta concluded with Photovost' s r o. HOOS appealed against the order of the Slovak court, which denied to grant the consumer protection association leave to intervene in the enforcement proceedings. HOOS claimed that the national court failed to protect Mr Vašuta against an unfair arbitration clause of its own motion and

178 AG Wahl, n 174 above, paragraphs 84-88.

179 AG Wahl, n 174 above, paragraph 97.

180 Case 618/10, n 78 above.

181 Case 415/11, n 98 above. 
missed to draw all the consequences out of the omission to state the annual percentage rate of charge in the consumer credit contract.

\section{bb) Opinion of Advocate-General Wahl}

The admissibility of the preliminary reference by the Slovak court is in question as Photovost' withdrew its action for enforcement of the arbitration award against Mr Vašuta. However, as the legal effects of the withdrawal of the action are uncertain, Advocate-General Wahl proposes that the preliminary reference is admissible. ${ }^{182}$ He thereby draws on the spirit of cooperation and trust between the national courts and the CJEU in the preliminary ruling procedure, which must prevail over the submission made by one of the parties to the dispute. ${ }^{183}$

Advocate-General Wahl concluded that Directive 93/13 and the principle of effectiveness do not preclude a national procedural rule, which denies consumer protection associations the right to intervene into legal proceedings between an individual consumer and a seller or supplier. In order to reach this conclusion, he clarified the different roles of the national courts and consumer protection associations under the Directive. It is the duty of the national court to compensate for the imbalance which exists between an individual consumer and a seller or supplier by assessing of its own motion whether a contractual term falling within the scope of Directive 93/13 is unfair and by ensuring that the consumer is not bound by an unfair term. The intervention by the national court guarantees the effective protection of the consumer against unfair terms. ${ }^{184}$ However, Directive 93/13 does not foresee a role for consumer protection associations in legal proceedings between an individual consumer and a seller or supplier. The Directive requires that consumer protection associations, if regarded as having a legitimate interest in the matter, have facilities for initiating proceeding against unfair terms in their own right. Those measures have a deterrent nature and aim to prevent the continued use of unfair terms independent from individual proceedings. ${ }^{185}$ However, as the Member States may adopt more stringent provisions in the area covered by the Directive, they are not precluded to grant consumer protection associations leave to intervene into legal proceedings. Such a measure could enhance the level of consumer protection, particularly if the consumer

182 AG Wahl, opinion of 12.12.2013 - case 470/12 Photovost's r o v Miroslav Vašuta, paragraph 36.

183 AG Wahl, n 182 above, paragraphs 37 and 38.

184 AG Wahl, n 182 above, paragraphs 53-56.

185 AG Wahl, n 182 above, paragraphs 59-62. 
protection associations inform the national court of certain terms, which were considered to be unfair by other national courts. ${ }^{186}$

\section{cc) Integration in the case-law}

The case addresses the position of consumer protection associations under EU law when it comes to assisting consumers in pursuing their claims in court. It demonstrates how substantive and procedural law in the field of consumer protection are inter-related. However, according to Advocate-General Wahl, the question referred to the CJEU is neither directly nor indirectly governed by EU law: This issue is said not to be addressed by Directive 93/13. Articles 38 and 47 of the Charter do not support a different interpretation of the Directive in the sense that it would provide for a right of consumer protection associations to intervene in individual enforcement proceedings. The rather narrow reading does not seem to be in line with the move the CJEU made in Aziz, in which the CJEU deduced from secondary Community law a new remedy to ask for injunctive relief to hold the enforcement procedure where the mortgage contract contains unfair contract terms. $^{187}$

\section{Doorstep selling (Case C-227/08 Martín Martín; case C-215/08 E. Friz; case C-166/11 González Alonso)}

\section{a) Legal consequences of the consumer's lack of information on his right of cancellation (Case C-227/08 Martín Martín)}

\section{aa) Facts}

The Spanish Audiencia Provincial de Salamanca asked if, according to Article 4 of Directive 85/577/EEC, ${ }^{188}$ a national court may raise, of its own motion, an infringement of that provision and declare the contract void on the ground that the consumer was not informed of his right of cancellation. The consumer is required under Spanish law to seek annulment of the contract where, upon its conclusion, the requirement to inform the consumer of his right of cancellation has not been met. Moreover, under the Spanish Law on Civil Procedure the principle that the parties delimit the subject-matter of the proceedings applies, under which the

186 AG Wahl, n 182 above, paragraphs 71 and 72.

187 Micklitz, n 111 above.

188 Council Directive 85/577/EEC of 20 December 1985 to protect the consumer in respect of contracts negotiated away from business premises, OJ 1985 L372/31. 
court cannot examine of its own motion facts, evidence and claims which the parties have not invoked.

In the case at hand, the consumer concluded a contract in a doorstep situation for the purchase of 15 books, five DVDs and a DVD player. Since the goods had not been paid for, the company applied for an order for payment. The referring court took the view that the contract could potentially be annulled because the consumer was not properly informed about her right of cancellation. The consumer, however, had not argued for the annulment of the contract.

\section{bb) Main reasoning}

Referring to the van Schijndel ${ }^{189}$ case, the CJEU made it clear that Community law does not, in principle, require national courts to raise of their own motion an issue concerning the breach of provisions of Community law, except in situations where their intervention can be required in the public interest. ${ }^{190}$ Following Hamilton $^{191}$ and Heiniger, ${ }^{192}$ the Court emphasizes the obligation to give notice to the consumer according to Article 4 of the Directive as an essential guarantee for the effective exercise of the right of cancellation and a component of the public interest. A positive intervention by the national court may be justified in order to achieve a balance between the consumer and the trader in the case of offpremises contracts. Therefore, the national court may determine of its own motion whether the consumer has been informed of his right of cancellation. ${ }^{193}$

Article 4 of the Directive leaves discretion to the national authorities to determine the consequences of a breach of the obligation to give notice, provided that that discretion is exercised in conformity with the Directive's aim of safeguarding the protection granted to consumers under appropriate conditions with regard to the particular circumstances of the case. ${ }^{194}$ The Directive provides for a minimum level of harmonisation inasmuch as, under Article 8, the Directive does not prevent Member States from adopting or maintaining more favourable provi-

189 Joined cases 430/93 and 431/94 Jeroen van Schijndel und Johannes Nicolaas Cornelis van Veen v Stichting Pensioenfonds voor Fysiotherapeuten [1995] ECR I-4705 (CJEU), paragraphs 21, 22.

190 Case 227/08 Eva Martín Martín v EDP Editores SL [2009] ECR I-11939 (CJEU), paragraphs 19, 20.

191 Case 412/06 Annelore Hamilton v Volksbank Filder eG [2008] ECR I-2383 (CJEU), paragraphs 32, 33.

192 Case 481/99 Georg Heininger und Helga Heininger v Bayerische Hypo- und Vereinsbank AG [2001] ECR I-9945 (CJEU), paragraph 45.

193 Case 227/08, n 190 above, paragraphs 27-29.

194 Case 227/08, n 190 above, paragraph 32. 
sions to protect consumers in the field which it covers. ${ }^{195}$ Declaring the contract in dispute void can be categorised as 'appropriate' within the meaning of Article 4 of the Directive. This does however not rule out the possibility that other measures might also ensure that level of protection, such as, for example, the resetting of the relevant time-limits relating to the cancellation of the contract. Referring to Pannon GSM, ${ }^{196}$ the CJEU added that the national court may take into account that the annulment is not always the wish of the consumer. ${ }^{197}$ Advocate-General Trstenjak comes to the conclusion that absolute nullity of the contract, which the national court declares of its own motion if the consumer has not been informed of his right of cancellation, is not an appropriate consumer protection measure. The nullity of the contract could be not to the benefit of the consumer, because the consumer is obliged by Spanish law to return the goods in return for the purchase price already paid. According to the Advocate-General, the national court is obliged ex officio to determine whether the consumer has been informed of his right to cancel the contract and, in case of a breach, it must inform the consumer of his right in accordance with the consumer's private autonomy. ${ }^{198}$

\section{cc) Integration in the case law}

Considering Mostaza Claro ${ }^{199}$ and Pannon $G S M,{ }^{200}$ it seems likely that the national courts are obliged to verify compliance with the Directive 85/577/EEC ex officio. The rather vague formulations, however, which indicate an authority rather than an obligation, seem to be based on the formulation of the question referred by the Spanish court. ${ }^{201}$

195 Case 227/08, n 190 above, paragraph 33.

196 Case 243/08, n 2 above, paragraph 33.

197 Case 227/08, n 190 above, paragraphs 34-35.

198 AG Trstenjak, opinion of 7.5.2009 - case 227/08, n 190 above, paragraphs 75-86.

199 Case 168/05, n 4 above.

200 Case 243/08, n 2 above.

201 Ebers, n 25 above, 833; see also, M. Depince, case note, (2011) 2 Revue européenne de droit de la consommation 383. 


\section{b) Application of Directive $85 / 577 / \mathrm{EEC}$ to the cancellation of a closed-end real property fund established in the form of a civil-law partnership (Case C-215/08 E. Friz)}

\section{aa) Facts}

The German Bundesgerichtshof asked the CJEU two questions relating to the cancellation of an investment in a closed-end real property fund. In its first question, it wanted to know whether the Directive 85/577 applies to a contract concerning a consumer's entry into a closed-end real property fund established in the form of a partnership and creating a contractual relationship between the consumer and the manager of that fund when the principal purpose of joining is not to become a member of that partnership, but is a means of capital investment. ${ }^{202}$ The court also asked whether Article 5(2) of the Directive precludes a national judge-made law according to which the consumer has a claim against that partnership, to his severance balance, calculated on the basis of the value of his interest at the date of his retirement from membership, and may therefore get back less than the value of his capital contribution or have to participate in the losses of that fund.

This case has to do with the wider issue of the acquisition of holdings in old real property in Germany known as 'Schrottimmobilien' (junk property). Investment in such property was opted for primarily on account of the resultant tax benefits, but has often failed to deliver the expected results. ${ }^{203}$ The consumer had joined a closed-end real estate fund which had the legal form of a civil-law partnership. After the consumer terminated without notice his participation in that partnership, the partnership demanded the payment of $€ 16,319$ as a negative severance balance, which was the difference between the value of the original investment and the consumer's share of losses which had been incurred by that partnership at the date that membership was cancelled. The appeal court rejected any payment obligation on the part of the consumer, as the consumer should not be subject to any more obligations under the cancelled contract in accordance with Article 5(2) of the Directive.

202 The question of the German Federal Court of Justice covered not only the accession of a consumer to a closed-end real property fund in the form of a partnership, but also to other types of companies or associations, such as commercial partnerships, associations and cooperatives. However, the CJEU came to the conclusion that it was not competent to answer this question with respect to the other types of societies and associations, see case 215/08 E. Friz GmbH v Carsten von der Heyden [2010] ECR I-2947 (CJEU), paragraphs 22-24.

203 On the scope and nature of the phenomenon, see: P. Derleder, 'Bankschaden und Bankrecht' (2003) 29 Neue Juristische Wochenschrift 2064. 


\section{bb) Main reasoning}

The entry of a consumer into a closed-end real property fund in the form of a partnership satisfies the conditions in Article 1(1) of Directive 85/577/EEC. ${ }^{204}$ Advocate-General Trstenjak had, however, held that the conditions governing the existence of a contract within the meaning of Article 1(1) were not given, as neither the initiator or founder nor the intermediary could be regarded as a 'trader' in the sense of Article 2 of the Directive. ${ }^{205}$ The CJEU, in contrast, made it clear that the investment intermediary, acting expressly as manager of the real property fund and earning a commission from that fund for every contract concluded with a new partner, was commercially active. ${ }^{206}$ The CJEU also rejected the argument of the German Government that the agreement concerned 'other rights relating to immovable property' within the meaning of the exclusion in Article 3(2)(a) of the Directive. ${ }^{207}$ As highlighted in Heiniger, ${ }^{208}$ derogations from the Union legislation on consumer protection must be strictly construed. ${ }^{209}$ This contract is exclusively concerned with joining a closed-end real proper fund by means of the acquisition of holdings in a partnership in exchange for a capital investment. 210

Article 5(2) does not preclude the national judge-made rule which entitles the consumer only to his severance balance in case he exercises his right to cancellation. Although the Directive was designed to protect consumers, this does not mean that the protection is 'absolute'.211 In Schulte, ${ }^{212}$ the CJEU made it clear that there is nothing in the Directive to preclude the consumer, in certain specific cases, from having obligations to the trader and, depending on the circumstances, from having to bear certain consequences resulting from the exercise of his right of cancellation. ${ }^{213}$ As the Bundesgerichtshof had stated, the German rule at issue sought a satisfactory balance and a fair division of the risks among the various interested parties in accordance with the general principles of civil law. ${ }^{214}$

204 Case 215/08, n 202 above, paragraph 30.

205 AG Trstenjak, opinion of 8.9.2009 - case 215/08, n 202 above, paragraphs 60-70.

206 Case 215/08, n 202 above, paragraphs 28, 29.

207 Case 215/08, n 202 above, paragraph 31.

208 Case 481/99, n 192 above, paragraph 31.

209 Case 215/08, n 202 above, paragraph 32.

210 Case 215/08, n 202 above, paragraph 33.

211 Case 215/08, n 202 above, paragraph 44. Under device to case 412/06, n 191 above, paragraphs 39, 40.

212 Case 350/03 Elisabeth Schulte and Wolfgang Schulte v Deutsche Bausparkasse Badenia AG [2005] ECR I-9215 (CJEU), paragraph 93.

213 Case 215/08, n 202 above, paragraph 45.

214 Case 215/08, n 202 above, paragraph 48. 
The consumer can recover his holding and take over a portion of the investment risk, and thus the other partners and third-party creditors would be exempt from the financial burden of the cancellation. ${ }^{215}$ As a result, the CJEU agrees with the opinion of Advocate-General Trstenjak, who also affirmed the compatibility of the national judge-made rule with the Directive for the case that the CJEU finds that Directive $85 / 577$ is applicable. ${ }^{216}$

\section{cc) Integration in the case-law}

According to the case-law of the German Bundesgerichtshof, the judge-made law at issue is applicable where the consumer withdraws his membership of a partnership. ${ }^{217}$ The purpose of reducing the entitlement of the consumer to his severance balance should lie in a fair balance of interests between the withdrawing consumer, the co-partners and third party creditors. ${ }^{218}$ The applicability of the Directive to private companies is partially critically debated. ${ }^{219}$ It is discussed whether the decision is transferable to other types of companies. ${ }^{220}$ The prevailing opinion is in favor of upholding the judge-made law, pointing out that otherwise the protection of individual consumers comes at the detriment of the other co-partners, who are also consumers. This is the only way to avoid a race of investors to recover their holding. ${ }^{221}$ In addition, the consumer

215 Case 215/08, n 202 above, paragraph 49.

216 AG Trstenjak, n 205 above, paragraph 103.

217 BGH, 27.6.2006 - II ZR 218/04, Deutsches Steuerrecht 2006, 1664.

218 BGH, 5.5.2008 - IIZR 292/06, Wertpapier Mitteilungen 2008, 1026; see also J. Oechsler, 'Die Geschichte der Lehre von der fehlerhaften Gesellschaft und ihre Stellung im europäischen Gesellschaftsrecht' (2008) 34 Neue Juristische Wochenschrift 2471.

219 For a critical opinion F. Podewils, 'Haustürwiderrufsrichtlinie: Anwendung auf Personengesellschaften - Fortgeltung der Grundsätze der fehlerhaften Gesellschaft' (2010) 7 Europäisches Wirtschafts- und Steuerrecht 265, 269; P. Kindler and S. Libbertz, 'Gesellschaftsrechtliche Grenzen des Verbraucherschutzes: Die Anwendung der Haustürgeschäfterichtlinie und der Lehre von der fehlerhaften Gesellschaft auf den Beitritt zu einer Publikumspersonengesellschaft' (2010) 16 Neue Zeitschrift für Gesellschaftsrecht 603, 605; for a positive opinion C. Armbrüster, 'Rückabwicklung von Fondsbeteiligungen - deutsches Gesellschaftsrecht modifiziert europäisches Verbraucherschutzrecht' (2010) 16 Europäische Zeitschrift für Wirtschaftsrecht 614, 615.

220 Kindler and Libbertz, n 219 above, 605; W. Goette, case note, (2010) 17 Deutsches Steuerrecht 878, 881; C. Schäfer, 'Fondsbeitritt an der Haustür - zu den Konsequenzen der Friz-Entscheidung des EuGH' (2010) 22 Deutsches Steuerrecht 1138; Podewils, n 219 above, 267.

221 Armbrüster, n 219 above, 616; Goette, n 220 above; A. Miras, case note, (2010) 21 Neue Juristische Wochenschrift 1511; for a critical view Podewils, n 219 above, 269; H. Schulte-Nölke, case note, (2009) LMK Anmerkung 275581. 
retains the possibility to claim damages against the promoters and founding shareholders. ${ }^{222}$

\section{c) Exclusion of unit-linked insurance contracts from the scope of Directive 85/ 577/EEC (Case C-166/11 González Alonso)}

\section{aa) Facts}

The Spanish Audiencia Provincial de Oviedo asked if according to Article 3(2)(d) of Directive 85/577/EEC a unit-linked life insurance contract negotiated away from business premises falls into the scope of this Directive.

The consumer requested the cancellation of the insurance contract and claimed the repayments of the premiums paid. The Spanish court considered that unit-linked insurance contracts are characterised by the fact that the insurer bears only the actuarial risk while the financial risk of the investment is transferred to the policyholder. It is the policyholder who assumes the risk in exchange for certain tax advantages. In the view of the national court, the contract may be classified not only as an insurance policy but also as a financial product. Only pure insurance contracts are, in accordance with Article 3(2)(d), excluded from the scope of Directive 85/577/EEC.

\section{bb) Main reasoning}

The CJEU ruled that Article 3(2)(d) of Directive 85/577/EEC also applies to unitlinked insurance contracts. The term 'insurance contract' must be given an autonomous and uniform interpretation throughout the European Union. ${ }^{223}$ Although derogations from the rules of European Union law for the protection of consumers must be interpreted strictly, a too narrow interpretation of Article 3(2) of Directive 85/577/EEC is excluded as the consumer protection under the Directive is not 'absolute' and subject to certain limits. ${ }^{224}$ Since unit-linked insurance

222 Miras, n 221 above; Schäfer, n 220 above, 1140, 1141; O. Mörsdorf, 'Überrumpelungsschutz gegen vertragsnahe Dritte? Der Anspruch des nicht über sein Haustürwiderrufsrecht belehrten Immobilienerwerbers auf Schadensersatz' (2012) 18 Zeitschrift für Wirtschaftsrecht 845; Armbrüster, $\mathrm{n} 219$ above, 616.

223 Case 166/11 Ángel Lorenzo González Alonso v Nationale Nederlanden Vida Cía de Seguros y Reaseguros SAE 1.3.2012 (CJEU), paragraph 25; as discussed by S. Weatherill, 'Consumer protection under EU law “is not absolute": yes, but be careful!' (2012) 2 European Review of Contract Law 221, 227-232.

224 Case 166/11, n 223 above, paragraphs 26, 27. 
contracts are common practice in insurance law, as is clear from Annex I point III in conjunction with Article 2(1)(a) of Directive 2002/83/EC concerning life insurance, ${ }^{225}$ it is assumed that the European Union legislature took this type of contract as belonging to a branch of life insurance. An identical approach follows from Article 1(1)(a) and point III of the Annex of the First Directive 79/267/EEC. ${ }^{226}$ These contracts are therefore not within the scope of Directive 85/577/EEC. This does not, however, exclude the policyholder from cancelling the insurance contract in accordance with Article 35(1) in conjunction with Article 36 and point A(a) 13 of Annex III of Directive 2002/83/EC. The requirements for this application are to be examined by the national court. ${ }^{227}$

\section{cc) Integration in the case-law}

The Consumer Rights Directive 2011/83/EU228 which came into force on 12.12.2011 does not lead to a different conclusion, since the exclusion of financial services in Article 3(3)(d) in conjunction with Article 2(12) encompasses insurance contracts. Some criticism has been directed against the overly narrow interpretation of the exception in Article 3(2)(d) of Directive 85/577/EEC. In Hamilton ${ }^{229}$ and E. Friz, ${ }^{230}$ the CJEU had found that consumer protection is not 'absolute'. However the CJEU had to balance different interests in those cases as for example, the equitable distribution of risk in a closed-end real estate fund against consumer protection. This was not the situation in the case at stake. Therefore, it would have been more convincing to limit the reasoning to the requirements set out by the European Union legislature. ${ }^{231}$

225 Directive 2002/83/EC of the European Parliament and of the Council of 5 November 2002 concerning life assurance, $O J 2002$ L345/1.

226 First Council Directive 79/267/EEC of 5 March 1979 on the coordination of laws, regulations and administrative provisions relating to the taking up and pursuit of the business of direct life assurance, OJ $1979 \mathrm{~L} 63 / 1$.

227 Case 166/11, n 223 above, paragraphs 29-33.

228 Directive 2011/83/EU of the European Parliament and of the Council of 25 October 2011 on consumer rights, amending Council Directive 93/13/EEC and Directive 1999/44/EC of the European Parliament and of the Council and repealing Council Directive 85/577/EEC and Directive 97/7/EC of the European Parliament and of the Council, OJ 2011 L304/64.

229 Case 412/06, n 191 above, paragraph 39.

230 Case 215/08, n 202 above, paragraph 44.

231 Weatherill, $\mathrm{n} 223$ above, 227-232. 


\section{Distance selling (Case C-205/07 Gysbrechts and Santurel Inter; case C-489/07 Messner; case C-511/08 Heinrich Heine; case C-49/11 Content Services)}

a) Prohibition on requiring from a consumer any payment or a credit card details before the end of the period for withdrawal (Case C-205/07 Gysbrechts and Santurel Inter)

\section{aa) Facts}

In the preliminary reference from the Belgian Hof van Beroep te Gent, the CJEU had to take a position on the question whether or not Articles 34-36 TFEU (ex Articles 28-30 EC) preclude the Belgian law implementing the Distance Selling Directive 97/7/EC, ${ }^{232}$ which prohibits the supplier from requiring a credit card number or any kind of payment before the expiry of the period for withdrawal of seven working days, even if the seller agrees not to use it before the end of the withdrawal period.

The Belgian retailer of food supplements required a French customer to furnish the number and validity period of his credit card before the expiry of the period for withdrawal. According to the terms and conditions of the online retailer, goods delivered in Belgium could be paid for by bank transfer, postal order or by credit card. For orders from other countries, however, only credit cards were accepted as payment. If a payment was made by credit card, the customer must specify the number and expiry date of the card on the purchase order. The trial court sentenced the business and its general manager to a fine of $€ 1,250$ each.

\section{bb) Main reasoning}

The CJEU clarified, first, that the contested regulation falls within the scope of Directive 97/7/EC which, in accordance with Article 14(1), consisted of only minimum harmonization and thus allowed for more stringent national rules in favour of a higher level of consumer protection. Any national regulations going beyond the Directive are to be measured against the provisions of EC Treaty. ${ }^{233}$ Since the proceedings at issue do not concern the importing of goods to Belgium, but only the export of goods from Belgium to other Member States, the CJEU

232 Directive 97/7/EC of the European Parliament and of the Council of 20 May 1997 on the protection of consumers in respect of distance contracts, OJ $1997 \mathrm{L144/19.}$

233 Case 205/07 Lodewijk Gysbrechts and Santurel Inter BVBA [2008] ECR I-9947 (CJEU), paragraphs 32-35. 
excluded the application of Article 34 TFEU (ex Article 28 EC). ${ }^{234}$ On the compatibility of national legislation with Article 35 TFEU (ex Article 29 EC), the CJEU referred to the test established in Groenveld ${ }^{235}$ for the definition of measures having equivalent effect to quantitative restrictions on exports. ${ }^{236}$ Even if the clause formally applies to all national operators, exports were actually more affected than the sale of goods on the domestic market. The national ban deprived the trader of an effective tool to protect himself against the risk of non-payment, the consequences of which were even more severe for cross-border direct selling. Therefore, the national legislation must be regarded as a measure having equivalent effect to a quantitative restriction on exports. ${ }^{237}$ In contrast, Advocate-General Trstenjak rejected the findings of the national court that it is more difficult and more onerous to recover sums from consumers established in other Member States. The seller need not always sue the consumer in the Member State in which the consumer has his habitual residence, and the Community has already adopted a number of measures in the field of judicial cooperation in civil matters having cross-border implications. ${ }^{238}$ However, Advocate-General Trstenjak came to the same conclusion as the CJEU, since she rejected the narrow application of the Groenveld test and pleaded for an adapted formulation drawn from Dassonville, ${ }^{239}$ Cassis de Dijon ${ }^{240}$ and Keck and Mithouard. ${ }^{241}, 242$

In its examination of Article 36 TFEU (ex Article 30 EC), the CJEU refers to Cassis de Dijon ${ }^{243}$ and A-Punkt Schmuckhandel ${ }^{244}$ and determines whether the Belgian legislation can be justified on the basis of the consumer protection goals pursued. ${ }^{245}$ In principle, the Belgian legislation is likely to achieve a high level of consumer protection in case of distance contracts, especially in relation to the

234 Case 205/07, n 233 above, paragraph 36.

235 Case 15/79 P B Groenveld BV v Produktschap voor Vee en Vlees [1979] ECR 3409 (CJEU), paragraph 7.

236 Case 205/07, n 233 above, paragraph 40.

237 Case 205/07, n 233 above, paragraphs 41-44.

238 AG Trstenjak, opinion of 17.7.2008 - case 205/07, n 233 above, paragraphs 38, 39.

239 Case 8/74 Procureur du Roi v Benoît and Gustave Dassonville [1974] ECR 837 (CJEU).

240 Case 120/78 Rewe-Zentral AG v Bundesmonopolverwaltung für Branntwein [1979] ECR 649 (CJEU).

241 Joined cases 267/91 and 268/91 Bernard Keck and Daniel Mithouard [1993] ECR I-6097 (CJEU).

242 AG Trstenjak, n 238 above, paragraphs 49 et seq.

243 Case 120/78, n 240 above, paragraph 8.

244 Case 441/04 A-Punkt Schmuckhandels GmbH v Claudia Schmidt [2006] ECR I-2093 (CJEU), paragraph 27.

245 Case 205/07, n 233 above, paragraph 47. 
exercise of the right to withdraw. ${ }^{246}$ Even if the prohibition on requiring a payment during the period for withdrawal increases the uncertainty of suppliers as to whether the price for the delivered goods will be paid, that prohibition is clearly necessary to ensure the level of protection intended by the national provision. ${ }^{247}$ However, to impose on a supplier a prohibition on requiring that a consumer provides his credit card number goes beyond what is necessary to attain the objective pursued and is incompatible with Article 35 TFEU. ${ }^{248}$

\section{cc) Integration in the case-law}

The significance of the judgment lies in the interpretation of Article 35 TFEU. Even if the CJEU, contrary to the suggestion of the Advocate-General, applied the Groenveld test, it only explicitly considered the second criterion, namely whether the measure gives rise to a difference in treatment between the domestic trade of a Member State and its export trade. The CJEU thus pushed aside the first criterion of the Groenveld test, whether the object or effect of the measure is the restriction specifically of patterns of exports, as well as the third requirement, whether the measure provides a particular advantage for national production or for the domestic market of the State in question, at the expense of the trade or production of other Member States. By means of the broad interpretation of the otherwise restrictive Groenveld test, the CJEU fits it into its case-law in Keck, leading to a convergence of standards. ${ }^{249}$

This result is welcomed in the literature, since, as pointed out by AdvocateGeneral Trstenjak, first, the difference in treatment under the Groenveld test cannot be detected when a product destined for export is not marketed domestically; secondly, because Article 34 and 35 TFEU pursue the same objective, namely the elimination of all barriers to trade flows in intra-Community trade'; and, thirdly, because it represents a departure from the Groenveld test towards a

246 Case 205/07, n 233 above, paragraph 52.

247 Case 205/07, n 233 above, paragraph 56.

248 Case 205/07, n 233 above, paragraphs 60-62. The CJEU refers to para 85 of the opinion of Advocate-General Trstenjak which turns on striking a fair balance between a high level of consumer protection and the protection of the seller against the risk that the consumer does not pay.

249 B. Schinkels, case note, (2009) LMK Anmerkung 275639; A. Brigola, 'Die Figur der Marktaustrittsbeschränkungen als Korrelat der Figur der Marktzugangsbeschränkungen - Zur Kohärenz der EG-Grundfreiheiten anlässlich des Urteils des EuGH vom 16.12.2008 - C-205/07 - Gysbrechts u.a.' (2009) 14 Zeitschrift für Europäisches Wirtschaftsrecht 479, 481, 482; W.H. Roth, case note, (2010) 2 Common Market Law Review 509, 514, 515. 
gradual standardization of the fundamental freedoms. ${ }^{250}$ Micklitz and Reich, however, observe critically that the minimum harmonization nature of the Directive could be abolished through the 'back door' as a result. ${ }^{251}$

As is generally known, a restriction on the free movement of goods can be justified on the grounds of consumer protection. Thus, a parallelization of written and unwritten grounds of justification in terms of both Article 34 and Article 35 is ensured..$^{252}$ In contrast, Article 5(2) of the Rome Convention of 1980 and Article 6 (1) of the Rome I Regulation prioritize the mandatory consumer protection provisions of the country in which the consumer has his habitual residence. In Alpine Investments, ${ }^{253}$ the CJEU still rejected the extraterritorial extension of the public interest. ${ }^{254}$ One criticism, from the consumer's point of view, is that they are saddled with the risk of the seller abusing the credit card payment and going bankrupt before the expiry of the cancellation period. ${ }^{255}$ Article 9(3) of Directive 2011/83/EU allows Member States to maintain existing national legislation on distance contracts 'prohibiting the trader from collecting the payment from the consumer during the given period after the conclusion of the contract.'

\section{b) Compensation for consumer's use of the goods supplied in the event of withdrawal within the withdrawal period (Case C-489/07 Messner)}

\section{aa) Facts}

The Amtsgericht Lahr asked the CJEU whether Article 6(1) and Article 6(2) of Directive 97/7 preclude a provision of national law which provides that, in the case of withdrawal by a consumer within the withdrawal period, a seller may claim compensation for the value of the use of consumer goods acquired under a distance contract.

The consumer purchased a second-hand laptop on the internet. According to the terms and conditions of the seller, the purchaser would be liable to pay

250 Brigola, n 249 above, 482, 483; J. Gundel, 'Anwendung der Keck-Formel auf Beschränkungen der Warenausfuhr gem. Art. 29 EGV' (2009) 7 Juristische Arbeitsblätter 558, 560; Roth, n 249 above, 509 .

251 On the opinion of the Advocate-General: H.-W. Micklitz and N. Reich, 'Vollharmonisierung durch die Hintertür? Zur Kritik der Schlussanträge der GÄin Trstenjak v. 17.7.2008 in der Rs. C-205/07 - Gysbrechts' (2008) 9 Verbraucher und Recht 349, 350.

252 Gundel, n 250 above, 560; Roth, n 249 above, 515, 516.

253 Case 384/93 Alpine Investments v Ministerie van Financien [1995] ECR I-1141 (CJEU), paragraph 43.

254 Schinkels, n 249 above; Roth, n 249 above, 515-519.

255 On the opinion of the Advocate-General, Micklitz and Reich, n 251 above, 350. 
compensation for value in respect of deterioration in goods through use for their intended purpose in the event of withdrawal. After the buyer refused to repair the defect of the laptop for free, the consumer revoked the contract before the expiry of the cancellation period. Since the buyer refused to accept the return of the laptop, the consumer brought an action for the refund of the purchase price. In contrast, the buyer argued that the consumer is obliged to pay it compensation for value inasmuch as she had been using the laptop.

\section{bb) Main reasoning}

According to Article 6(1) and (2) of Directive 97/7/EC, no further cost than the direct cost of returning the goods shall be imposed on the consumer upon the exercise of his right of withdrawal. The $14^{\text {th }}$ recital clarifies that the right of withdrawal is 'to be more than formal'. ${ }^{256}$ The disadvantage of not being able actually to see the product or ascertain the nature of the service provided before concluding the distance contract should be compensated for by granting an appropriate period for reflection during which the consumer can examine and test the goods acquired. ${ }^{257}$ The general requirement to pay compensation, which would be paid solely because the consumer has the opportunity to use the goods until the expiry of his right of withdrawal, is contrary to the wording and purpose of Article 6(1) and (2) of Directive 97/7.258 A seller's right to compensation adversely affects the efficiency and effectiveness of the right of withdrawal. ${ }^{259}$

However, the Directive 97/7/EC provides the consumer with no rights that go beyond what is necessary for the effective exercise of this right. ${ }^{260}$ Article 6(1) and (2) of Directive 97/7/EC do not preclude national legislation which requires the consumer to pay a fair compensation if he has used the goods in a way which is incompatible with the 'principles of civil law, such as those of good faith or unjust enrichment.'261 The efficiency and effectiveness of the right of withdrawal would be adversely affected if the amount of compensation would be disproportionate to the purchase price of the goods or if the consumer would have to bear the evidential burden of proving that he did not use the product in a manner which went beyond what was necessary to permit him to make effective use of his right

256 Case 489/07 Pia Messner v Firma Stefan Krüger [2009] ECR I-07315 (CJEU), paragraph 19.

257 Case 489/07, n 256 above, paragraph 20.

258 Case 489/07, n 256 above, paragraphs 22, 23.

259 Case 489/07, n 256 above, paragraph 24.

260 Case 489/07, n 256 above, paragraph 25.

261 Case 489/07, n 256 above, paragraph 26. 
of withdrawal. ${ }^{262}$ It is the task of the national court, taking into account the circumstances of the concrete case, in particular the nature of the goods and the length of time at the end of which the consumer exercised his right of withdrawal, to decide whether a compensation obligation of the consumer for the use of the goods is appropriate. ${ }^{263}$

\section{cc) Integration in the case-law}

The decision of the CJEU has to correct many different opinions in German legal literature. ${ }^{264}$ The newly framed $\S 312 \mathrm{e}$ of the German Civil Code ${ }^{265}$ obliges the consumer in distance contracts, notwithstanding $\S 357(1)$, to pay compensation where he has used the goods in a way that goes beyond testing the properties and functioning (no 1), and if he has been informed by the seller of this legal consequence and in accordance with $\S 360$ (1) or (2) of his right to withdraw and to return goods or otherwise has knowledge of both (no 2). The first condition allows the consumer to inspect the goods as would normally be the case in a shop. To ensure the effectiveness of the right of withdrawal in accordance with the interpretation of the CJEU, the presence of both conditions has to be proven by the seller. ${ }^{266}$ As pointed out by Advocate-General Trstenjak, a possible abuse by individual consumers must not result in a general restriction of rights guaranteed under Community law. ${ }^{267}$ Article 14(2) of Directive 2011/83/EU implements the CJEU's decision in the Messner case. ${ }^{268}$

262 Case 489/07, n 256 above, paragraph 27.

263 Case 489/07, n 256 above, paragraph 28.

264 See for example B. Schinkels, case note, (2009) LMK Anmerkung 291092; O. Damm, case note, (2009) 11 MultiMedia und Recht 744.

265 Law of 27.7.2011 (BGBl I, 1600); see also A. Bartholomä, 'Die Systematik des neuen Wertersatzregimes nach Widerruf' (2012) 25 Neue Juristische Wochenschrift 1761; C. Wendehorst, 'Dauerbaustelle Verbrauchervertrag: Wertersatz bei Widerruf von Fernabsatzverträgen’ (2011) 35 Neue Juristische Wochenschrift 2551.

266 P. Rott, 'The Balance of Interests in Distance Selling Law - Case Note on Pia Messner v. Firma Stefan Krüger' (2010) 1 European Review of Private Law 185, 190, 191.

267 AG Trstenjak, opinion of 18.2.2009 - case 489/07, n 256 above, paragraph 90.

268 P. Rott, 'More coherence? A higher level of consumer protection? - A review of the new Consumer Rights Directive 2011/83/EU' (2012) 3 Revue européenne de droit de la consommation 371, 384. 


\section{c) Refund of the delivery costs in case of revocation of a distance contract (Case C-511/08 Heinrich Heine)}

\section{aa) Facts}

The German Bundesgerichtshof asked the CJEU whether the provisions of Article 6(1) and (2) of Directive 97/7/EC preclude national legislation which provides that the cost of delivering the goods can be charged to the consumer upon withdrawal.

The mail-order company provided in its general terms and conditions that the consumer, in case of withdrawal, would not be refunded the delivery charge. The consumer organization brought an action against the company for an injunction to restrain it from charging consumers the cost of delivering the goods in the event of withdrawal. The lower court agreed with the consumer organization. The German Federal Court of Justice referred in its submission to several arguments that could suggest that the Directive 97/7/EC does not preclude the national legislation at stake.

\section{bb) Main reasoning}

The CJEU dealt first with the meaning of the phrase 'sums paid by the consumer' in Article 6(2). All payments made by the consumer in connection with the contract would be covered. The wording 'the only charge' in Article 6(2) confirms that a strict interpretation is appropriate. ${ }^{269}$ In order to interpret the phrase 'because of the exercise of his right of withdrawal', the CJEU relied on the purpose and general scheme of the rules of which the provision forms part. ${ }^{270} \mathrm{To}$ ensure that the right of withdrawal of the consumer is 'more than formal', the costs that are born by the consumer as a result of exercising the right of withdrawal must be limited to the direct cost of returning the goods. ${ }^{271}$ The imposition of delivery costs could dissuade the consumer from exercising his right to withdrawal and would run counter to the objective of the Directive. ${ }^{272}$ The fact that the consumer has been informed of the amount of the delivery costs prior to concluding the contract cannot neutralise the dissuasive effect which the charging of those costs to the consumer would have on his exercise of his right of

269 Case 511/08 Handelsgesellschaft Heinrich Heine GmbH v Verbraucherzentrale NordrheinWestfalen eV [2010] ECR I-03047 (CJEU), paragraphs 45-47.

270 Case 511/08, n 269 above, paragraph 51.

271 Case 511/08, n 269 above, paragraphs 54, 55. With reference to the recital 14 of Directive 97/ 7/EC and the case law of the CJEU in case 489/07, n 256 above, paragraph 19.

272 Case 511/08, n 269 above, paragraph 56. 
withdrawal. ${ }^{273}$ Moreover, charging the consumer would compromise a balanced sharing of the risks between parties to distance contracts, by making consumers liable to bear all of the costs related to transporting the goods. ${ }^{274}$

\section{cc) Integration in the case-law}

Contrary to the opinions of the German government, the CJEU made clear that the mail-order company should not impose the costs for sending the goods on the consumer. The result is economically fair, since the consumer is adequately involved by the imposition of the return costs. ${ }^{275}$ The additional burden on the distance selling company would be compensated for by the savings in the cost of rental of stores and sales staff. ${ }^{276}$ Offers whereby goods are shipped for free (ie shipping costs are included in the purchase price) remain attractive for companies. It would create no incentive to lower the purchase price and offset this by setting the shipping costs higher in order to secure a concealed profit in the event of cancellation. ${ }^{277}$ Directive 2011/83/EU on Consumer Rights provides in Article 13 (1) that the company has an obligation to repay the cost of delivery, unless the consumer has opted for a different more expensive type method of delivery than the standard delivery offered by the trader. According to Article 14(1), the consumer must bear the cost of returning the goods. ${ }^{278}$

\section{d) Consumer information on conclusion of a distance contract only available by hyperlink on the company website (Case C-49/11 Content Services)}

\section{aa) Facts}

The Austrian Oberlandesgericht Wien asked whether Article 5(1) of Directive 97/7 must be interpreted as meaning that a business practice consisting of making the information referred to in that provision accessible to the consumer only via a

273 Case 511/08, n 269 above, paragraph 58.

274 Case 511/08, n 269 above, paragraph 57.

275 U. Grohmann and N. Gruschinske, 'Versandkosten bei Fernabsatzgeschäften im Falle des Widerrufs - Kommentar zu den Schlussanträgen des Generalanwalts in der Rechtssache C-511/08' (2010) 7 Europäische Zeitschrift für Wirtschaftsrecht 245, 246.

276 D. Looschelders, 'Unzulässige Belastung des Verbrauchers mit Zusendungskosten bei Widerruf eines Fernabsatzvertrags’ (2010) 11 Juristische Arbeitsblätter 825, 826.

277 B. Schinkels, case note, (2010) LMK Anmerkung 303287.

278 Rott, $\mathrm{n} 268$ above, 384. 
hyperlink on a website of the undertaking concerned meets the requirements of that provision.

Content Services Ltd offers free software and trial versions of paid software to download on its website. To use the website, including accessing links which refer to the official sites of the program manufacturers, the customer must sign a subscription contract. The contract is concluded by filling out an online registration form on the company website. By ticking a box when submitting their contract, customer must agree at that point that they accept the general terms and conditions and waive their right of withdrawal. The information required under Articles 4 and 5 of the Directive, particularly the information concerning the right of withdrawal, is not shown directly to the customer who may, however, view it by clicking on a hyperlink on the contract sign-up page. After conclusion of the contract, the customer receives a confirmation e-mail containing his data and another link which provides information about the right of withdrawal. The customer subsequently receives an invoice, which reminds him that he has waived the right of withdrawal.

\section{bb) Main reasoning}

According to Article 5(1) of Directive 97/7/EC the consumer must already be 'given' the information referred to in Article 4(1) prior to conclusion of the contract or else the consumer can 'receive' the information during the performance of the contract through a confirmation. In both cases, the information must be submitted in writing or in another 'durable medium' available and accessible to the consumer. ${ }^{279}$ The CJEU concluded that the information is neither 'given to' nor 'received' by the consumer when it is only made accessible by a link. The consumer protection targeted by the Directive requires that the use of distance communication does not lead to a reduction of the information provided. ${ }^{280}$

The CJEU considered whether information on a website which is accessible for the consumer through a link is to be regarded as a 'durable medium'. A replacement for the paper forms was deemed acceptable if it fulfills the same function as the paper forms. ${ }^{281}$ Referring to the definitions of the term 'durable medium' in other European legislation ${ }^{282}$ and in the judgment of the EFTA Court

279 Case 49/11 Content Service Ltd v Bundesarbeitskammer 05.07.2012 (CJEU), paragraphs 28, 29.

280 Case 49/11, n 279 above, paragraphs 33-37; Referring to recital 11 of Directive 97/7/EC.

281 Case 49/11, n 279 above, paragraph 41.

282 Art 2(f) Directive 2002/65; art 2(12) Directive 2002/92; art 3(m) Directive 2008/48; art 2(10) Directive 2011/83. 
in Inconsult Institute/Finanzmarktaufsicht, ${ }^{283}$ the CJEU found that a medium must be regarded as 'durable' within the meaning of that provision where it allows the consumer to store the information which has been addressed to him personally, in a way that the information is accessible for an adequate period which gives the consumer the possibility to reproduce it unchanged and without the possibility of a unilateral change by the seller. ${ }^{284} \mathrm{~A}$ website whose information can only be accessed via a link cannot be regarded as a 'durable medium' under Article 5(1) of Directive 97/7/EC. ${ }^{285}$ The CJEU's judgment follows the conclusion of AdvocateGeneral Mengozzi. ${ }^{286}$

\section{cc) Integration in the case-law}

The case offered the CJEU the opportunity to address the requirements of information transfer in the context of new technologies. Even if the law must adapt to new technologies, this should not happen at the expense of consumer protection. ${ }^{287}$ The CJEU did not take a position on what kind of more developed sites could meet the requirements of a durable medium. ${ }^{288}$ A restriction to using only abstract criteria is to be welcomed in the light of new technological developments, as noted in the opinion of Advocate-General Mengozzi. ${ }^{289}$ The CJEU is criticized for departing from the idea of a completely passive consumer, although putting a hyperlink to surf the Internet is common. ${ }^{290}$ In order to avoid legal uncertainty, General Mengozzi suggests integrating the information directly into the text of the e-mail. In view of the strict and formalistic interpretation of the wording in Article 5(1) of the Directive, it remains to be seen whether anything will change due to the new wording of the Directive 2011/83/EU, which in Ar-

283 EFTA Court, 27.1.2010 - E-4/09 Inconsult Anstalt/Finanzmarktaufsicht Court Report 2009/ 2010, 86.

284 Case 49/11, n 279 above, paragraphs 43-45.

285 Case 49/11, n 279 above, paragraph 50.

286 AG Mengozzi, opinion of 6.3.2012 - case 49/11, n 279 above.

287 G. Brunaux, 'De l'utilisation de pages web pour l'exécution des obligations d'information d'un contrat conclu par la voie électronique' (2013) 7 Petites affiches. La Loi/Le Quotidien juridique 10; see also C. Goata, 'Information Duties in the Internet Era: Case Note on Content Services Ltd v. Bundesarbeitskammer' (2013) 2 European Review of Private Law 643.

288 Case 49/11, n 279 above, paragraphs 48-50.

289 AG Mengozzi, n 286 above, paragraph 17.

290 Brunaux, n 287 above. 
ticle $8(7)(a)$ requires that the supplier 'shall provide' the consumer the necessary information. ${ }^{291}$

\section{Sale of consumer goods (Joined cases C-65/09 Gebrüder Weber, C-87/09 Putz; case C-32/12 Duarte Hueros)}

\section{a) Obligation on the seller to remove the defective goods and install the replacement goods (Joined cases C-65/09 Gebrüder Weber, C-87/09 Putz)}

\section{aa) Facts}

The preliminary reference from the German Bundesgerichtshof (C-65/09) of 14 January 2009 and the Amtsgericht at Schorndorf (C-87/09) of 25 February 2009 concerned the interpretation of Article 3(2) and (3) of the Consumer Sales Directive 1999/44/EC. May the buyer also require the seller to cover the installation and removal costs based on the claim of replacement where the item purchased turns out to be deficient after installation? May the seller refuse the type of remedy required by the consumer when the remedy would result in the seller incurring costs which, compared with the value the consumer goods would have if there were no lack of conformity, and with the significance of the lack of conformity, would be unreasonable (absolutely disproportionate)?

In case C-65/09 (Gebrüder Weber GmbH v Jürgen Wittmer) the parties entered into a contract to purchase polished floor tiles for the price of EUR 1,382.27. After having had about two thirds of the tiles laid in his house, Mr Wittmer noticed that there was shading on the tiles which was visible to the naked eye. The appointed expert concluded that the shadings were fine micro-brush-marks which could not be removed, so that the only remedy possible was complete replacement of the tiles. The expert estimated the cost of this at EUR 5,830.57. The appeal court ordered Weber to deliver a new set of tiles free from defects and to pay Mr Wittmer EUR 2,122.37 for removing and disposing of the defective tiles. Weber appealed against that judgment before the Federal Court of Justice.

In case C-87/09 (Ingrid Putz v Medianess Electronics $\mathrm{GmbH}$ ), the parties concluded a contract to purchase a new dishwasher over the Internet. After the consumer had the dishwasher installed in her house, a defect, which could not be repaired, became apparent. The parties then agreed on the replacement of the

291 A. Stadtler and J. Weissel, 'Fernabsatz-Richtlinie: Hyperlink kein “dauerhafter Datenträger”, (2012) 4 European Law Reporter 117. 
dishwasher. The consumer demanded that Medianess Electronics delivered a new dishwasher, and also remove the defective machine and install the replacement machine or pay the costs of such. Since Medianess failed to respond to the notice, the consumer rescinded the contract of sale and brought proceedings against Medianess Electronics before the Local Court at Schorndorf seeking reimbursement of the purchase price against return of the defective dishwasher.

\section{bb) Main reasoning}

The CJEU ruled that the seller is obliged under Article 3(2) and (3) of the Directive, to restore the goods to conformity with the contract through the removal of the original goods and installation of the replacement goods, or bearing the cost of such, regardless of whether the installation was originally subject to the contract of sale. The CJEU relies largely on the wording of Article 3(2) and (3), the Quelle decision $^{292}$ and the purpose of the Directive to ensure a high level of consumer protection. The European Union legislature intended to make the 'free of charge' aspect of the seller's obligation to bring goods into conformity 'an essential element of the protection afforded to consumers by that directive' ${ }^{293}$ The consumer should be protected from risks of financial burdens which might dissuade him from asserting their rights. ${ }^{294}$ Although the removal and installation costs were not explicitly referred to in Article 3(4), that enumeration of the various types of cost is only illustrative and not exhaustive. ${ }^{295}$ The 'repair and replacement of goods not in conformity' is to be completed not only free of charge but also within a reasonable time and without significant inconvenience to the consumer pursuant to Article 3(3). ${ }^{296}$ Such an interpretation does not lead to an inequitable outcome. Even assuming that the non-conformity of goods was not the fault of the seller, by delivering goods not in conformity the seller fails correctly to perform the obligation which he accepted in the contract of sale, and must therefore bear the consequences of that. In contrast, the fact that the consumer, confident in the conformity of the goods delivered, installed the defective goods, in good faith, in a manner consistent with their nature and purpose, before the

292 Case 404/06 Quelle AG v Bundesverband der Verbraucherzentralen und Verbraucherverbände [2008] ECR I-02685 (CJEU); discussed by K. Lilleholt, (2010) 2 European Review of Contract Law 192.

293 Joined cases 65/09 Gebrüder Weber GmbH v Jürgen Wittmer and 87/09 Ingrid Putz v Medianess Electronics GmbH [2011] ECR I-05257, paragraph 46.

294 Cases 65/09 and 87/09, n 293 above, paragraph 46.

295 Cases 65/09 and 87/09, n 293 above, paragraph 50.

296 Cases 65/09 and 87/09, n 293 above, paragraph 52. 
defect became apparent, cannot be held against him as a fault. ${ }^{297}$ The seller's financial interests are protected by the two-year time-limit laid down in Article 5 (1) of the Directive and by the fact that, under the second subparagraph of Article 3(3) of the Directive, the seller may refuse to replace the goods where that remedy would be disproportionate in that it would impose unreasonable costs on him as well as the right of redress, reaffirmed in Article 4 of the Directive, against persons liable in the same contractual chain. ${ }^{298}$

Article 3(3) precludes national legislation which gives the seller the right to refuse replacement where it is the only possible type of remedy just because it would result in costs that would be disproportionate compared with the value of the non-defective consumer goods and the significance of the defect. Therefore if only one of the two remedies mentioned in Article 3(3) is possible, the seller may not refuse the only remedy which allows the goods to be brought into conformity with the contract. ${ }^{299}$ However, the consumer's right to reimbursement of the cost of removing the defective goods and installing the replacement goods can be limited, where necessary, to an amount proportionate to the value the goods would have if there were no lack of conformity and the significance of the lack of conformity. ${ }^{300}$ However, the possibility of making such a reduction must not result in the consumer's right to reimbursement of those costs being effectively rendered devoid of substance in practice. ${ }^{301}$ In such a situation, the consumer should be able to request, instead of replacement of the goods not in conformity, an appropriate price reduction or rescission of the contract. ${ }^{302}$ The CJEU comes to a different conclusion than the Advocate-General Mazák, who restricted his conclusions to a reasonable balance of interests between buyer and seller. ${ }^{303}$ Advocate-General Mazák refused to extend the duty owed by the seller to include disconnection the defective product and installing the new product free from defects unless the installation of the product formed part of the contract agreed between the seller and the consumer. ${ }^{304}$ The denial of a remedy because of an absolute lack of proportionality was compatible with the Directive. ${ }^{305}$

297 Cases 65/09 and 87/09, n 293 above, paragraph 56.

298 Cases 65/09 and 87/09, n 293 above, paragraph 58.

299 Cases 65/09 and 87/09, n 293 above, paragraph 71.

300 Cases 65/09 and 87/09, n 293 above, paragraph 74.

301 Cases 65/09 and 87/09, n 293 above, paragraph 76.

302 Cases 65/09 and 87/09, n 293 above, paragraph 77.

303 AG Mazák, opinion of 18.5.2010 - cases 65/09 and 87/09, n 293 above, paragraphs 48, 85.

304 AG Mazák, n 303 above, paragraph 67.

305 AG Mazák, n 303 above, paragraph 88. 


\section{cc) Integration in the case-law}

The CJEU established under the claim for subsequent performance a strict obligation of the seller to perform or to pay the costs incurred for the removal and replacement of the defective goods. The CJEU therefore interferes with the contractual balance between the parties, since the seller must provide additional services that were not provided in the contract. This would appear to call into question the exclusive legislative competence of the Member States relating to claims for damages in the sale of consumer goods. ${ }^{306}$ The judgment has been called in German literature a 'bang from Luxembourg'307 and 'consumer rights social romanticism'. ${ }^{308}$ Nevertheless, the practical implications are not entirely seen as consumer-friendly as it is expected that sellers will take these economic burdens into account in setting their prices. ${ }^{309}$

\section{b) Purchase price reduction of a defective product where rescission of the contract is excluded (Case C-32/12 Duarte Hueros)}

\section{aa) Facts}

The Spanish Juzgado de Primera Instancia ${ }^{\circ} 2$ of Badajoz referred to the CJEU the question, whether according to Directive 1999/44/EC a national court may of its own motion reduce the purchase price of a defective product if the consumer has sought only rescission of the contract, to which, however, he is not entitled owing to the minor nature of the defect.

The consumer purchased a car with a sliding roof from Autociba. As the roof of the convertible car turned out to be not watertight when it rained, the consumer returned the car to the seller. Following several unsuccessful attempts to repair the roof and Autociba's refusal to replace the car, the consumer initiated legal proceedigs seeking rescission of the sale contract and repayment of the purchase price. The national court refused to rescind the contract due to the minor nature of the lack of conformity. While the consumer is entitled to a reduction of the

306 B. Krebe, case note, (2012) 1 European Review of Private Law 255, 260; see also A. Fromont and C. Verdure, case note, (2012) 1 Revue européenne de droit de la consummation 141.

307 K. Purnhagen, 'Zur Auslegung der Nacherfüllungsverpflichtung - Ein Paukenschlag aus Luxemburg' (2011) 16 Europäische Zeitschrift für Wirtschaftsrecht 626.

308 S. Lorenz, 'Ein- und Ausbauverpflichtung des Verkäufers bei der kaufrechtlichen Nacherfüllung' (2011) 31 Neue Juristische Wochenschrift 2241, 2243.

309 Lorenz, n 308 above, 2243; J. Glöckner, 'Von Greenman v. Yuba zu Gebr. Weber und Putz der EuGH geht den nächsten Schritt auf dem Wege der Ökonomisierung des Europäischen Verbraucherprivatrechts' (2011) 9 Europäisches Wirtschafts- und Steuerrecht 359, 362; A. Johnston and H. Unberath, note, (2012) 2 Common Market Law Review 793, 807. 
purchase price, Spanish procedural law precludes the award of this remedy as the consumer did not, at least in the alternative, request a price reduction. The consumer is also unable to defer her claim for price reduction to later proceedings as the principle of res judicata covers all claims which could have been made, but were not made, in earlier proceedings.

\section{bb) Main reasoning}

The CJEU held that in the case where a consumer is entitled to a reduction of the purchase price but claims only the rescission of the contract, which is, however, excluded by the minor nature of the defect, and the consumer is not entitled to refine his initial application or to initiate new legal proceedings to that end, Directive 1999/44/EC precludes national legislation which does not allow the national court to grant of its own motion an appropriate reduction of the purchase price. Because the Directive does not indicate how the rights derived from the Directive are to be asserted in judicial proceedings, those procedural rules fall within the national procedural autonomy, subject to the principles of equivalence and effectiveness. ${ }^{310}$ While there is no apparent breach of the principle of equivalence, the Spanish procedural rules undermine the effectiveness of the consumer protection intended by the European Union legislature. ${ }^{311}$ In the situation at hand, the Spanish procedural system deprives the consumer of the possibility of benefitting from the right to seek an appropriate price reduction pursuant to Article 3(5) of Directive 1999/44, except where the consumer's application contains an alternative claim to that end. ${ }^{312}$ However, the CJEU regards this eventuality as very improbable either because of the strict requirement that the alternative claim has to be presented at the same time as the principal claim or because the consumer is not aware of the extent of his rights. ${ }^{313}$ The protection of the consumer under Article 3(5) of the Directive is rendered completly uncertain as the Spanish procedural rules oblige the consumer to anticipate the outcome of the analysis by the national court of the legal characterisation of the lack of conformity. ${ }^{314}$ In line with the observations of Advocate-General Kokott, the CJEU concluded that the Spanish procedural rules are in breach with the principle of effectiveness as they render it excessively difficult, if not impossible, for the consumer to exercise his

310 Case 32/12 Soledad Duarte Hueros v Autociba SA und Automóviles Citroën España SA 3.10.2013 (CJEU), paragraphs 30, 31.

311 Case 32/12, n 310 above, paragraphs 32, 33.

312 Case 32/12, n 310 above, paragraph 37.

313 Case 32/12, n 310 above, paragraph 38.

314 Case 32/12, n 310 above, paragraph 40. 
rights under the Directive 1999/44/EC in case the goods delivered are not in conformity with the contract. ${ }^{315}$ It is left to the national court to determine how to solve this issue guaranteeing the full effectiveness of Article 3(5) of Directive $1999 / 44.316$

\section{cc) Integration in the case-law}

It is interesting to note that Advocate-General Kokott expresses doubts as to the classification of the defect as 'minor' and mentions that the Spanish court should have referred also the question of what constitutes a minor nature of a defect for a preliminary ruling. There is no uniform interpretation of a 'minor' defect in EU law and other national courts have ruled in comparable cases that the entry of water is not to be regarded as a defect of minor nature. ${ }^{317}$

315 Case 32/12, n 310 above, paragraph 41.

316 Case 32/12, n 310 above, paragraph 42.

317 AG Kokott, opinion of 28.2.2013 - case 32/12, n 310 above, paragraphs 55-57. 